\title{
Phosphinocyclodextrins as confining units for catalytic metal centres. Applications to carbon-carbon bond forming reactions
}

\author{
Matthieu Jouffroy ${ }^{1}$, Rafael Gramage-Doria ${ }^{1}$, David Sémeril ${ }^{1}$, Dominique Armspach ${ }^{* 1}$, \\ Dominique Matt ${ }^{*}$, Werner Oberhauser ${ }^{2}$ and Loïc Toupet $^{3}$
}

\section{Full Research Paper}

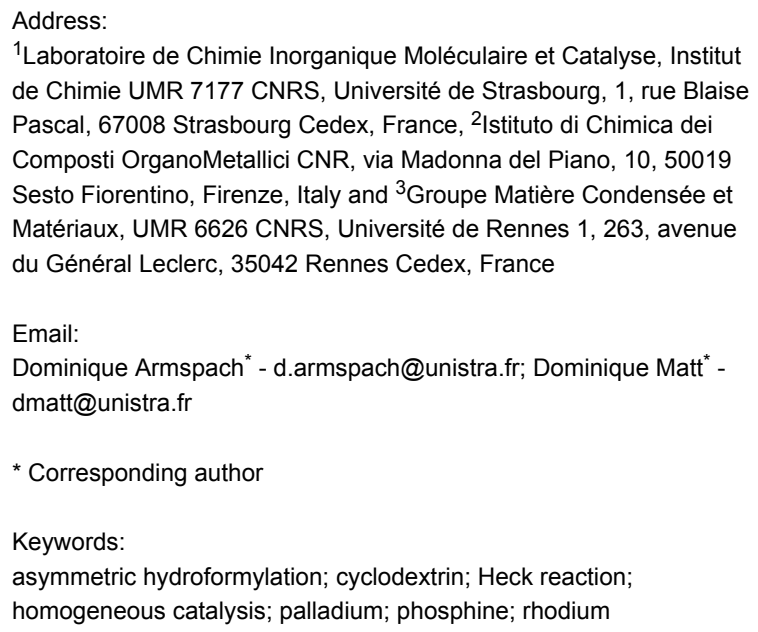

${ }^{1}$ Laboratoire de Chimie Inorganique Moléculaire et Catalyse, Institut de Chimie UMR 7177 CNRS, Université de Strasbourg, 1, rue Blaise Pascal, 67008 Strasbourg Cedex, France, ${ }^{2}$ Istituto di Chimica dei Composti OrganoMetallici CNR, via Madonna del Piano, 10, 50019 Sesto Fiorentino, Firenze, Italy and ${ }^{3}$ Groupe Matière Condensée et Matériaux, UMR 6626 CNRS, Université de Rennes 1, 263, avenue du Général Leclerc, 35042 Rennes Cedex, France

Email:

Dominique Armspach ${ }^{*}$ - d.armspach@unistra.fr; Dominique Matt ${ }^{*}$ dmatt@unistra.fr

* Corresponding author

Keywords:

asymmetric hydroformylation; cyclodextrin; Heck reaction;

homogeneous catalysis; palladium; phosphine; rhodium

\author{
Beilstein J. Org. Chem. 2014, 10, 2388-2405. \\ doi:10.3762/bjoc. 10.249
}

Received: 11 July 2014

Accepted: 09 September 2014

Published: 15 October 2014

This article is part of the Thematic Series "Superstructures with cyclodextrins: Chemistry and applications II".

Guest Editor: G. Wenz

(C) 2014 Jouffroy et al; licensee Beilstein-Institut. License and terms: see end of document.

\begin{abstract}
The capacity of two cavity-shaped ligands, HUGPHOS-1 and HUGPHOS-2, to generate exclusively singly phosphorus-ligated complexes, in which the cyclodextrin cavity tightly wraps around the metal centre, was explored with a number of late transition metal cations. Both cyclodextrin-derived ligands were assessed in palladium-catalysed Mizoroki-Heck coupling reactions between aryl bromides and styrene on one hand, and the rhodium-catalysed asymmetric hydroformylation of styrene on the other hand. The inability of both chiral ligands to form standard bis(phosphine) complexes under catalytic conditions was established by high-pressure NMR studies and shown to have a deep impact on the two carbon-carbon bond forming reactions both in terms of activity and selectivity. For example, when used as ligands in the rhodium-catalysed hydroformylation of styrene, they lead to both high isoselectivity and high enantioselectivity. In the study dealing with the Mizoroki-Heck reactions, comparative tests were carried out with WIDEPHOS, a diphosphine analogue of HUGPHOS-2.
\end{abstract}

\section{Introduction}

Since the studies of Fu, Buchwald and Hartwig on the use of monophosphine ligands in cross-coupling reactions, notably carbon-carbon ones such as the Mizoroki-Heck [1-3] and

Suzuki-Miyaura reactions [4-6], there is a renewed interest for tertiary phosphines that favour the formation of singly phosphorus-ligated complexes when opposed to transition metal 
ions. Such a behaviour, which was shown to have a deep impact on the catalyst performance, is classically observed with very bulky monophosphines [1,7-10], including dendrimeric ones $[11,12]$, and is also found with hybrid ligands displaying hemilability so as to prevent the coordination of a second phosphorus atom $[13,14]$ or cavity-shaped phosphines [15]. The use of sterically-hindered P(III)-derivatives, notably phosphites [1621 , has also proven beneficial in yet another carbon-carbon forming reaction, namely the rhodium-catalysed hydroformylation [22] of $\alpha$-olefins [23-29]. By favouring the formation of singly phosphorus-ligated complexes, these ligands not only improve the catalyst activity, but also its regioselectivity, the branched regioisomer(s) being formed at the expense of the linear one. However, when it comes to enantioselectivity, only one chiral mono-P(III) ligand [30-32] has so far shown some potential in the notoriously challenging, but industrially relevant asymmetric hydroformylation [33-37]. Recently, we have synthesised a new type of chiral phosphine ligand (HUGPHOS1 [38] and HUGPHOS-2 [39], see Figure 1), which consists of methylated cyclodextrins (CD) equipped with an embedded phosphorus atom. In contrast to previously reported monophosphines [40-43] based on methylated CDs [41-44], our ligands have confining properties because of the presence of an inwardpointing $\mathrm{P}(\mathrm{III})$ atom $[44,45]$. The present study is concerned with the ability of HUGPHOS-1 and HUGPHOS-2 to generate exclusively singly P(III)-ligated complexes with a number of $d^{6}$ and $d^{8}$ metal cations and the evaluation of the catalytic properties of palladium and rhodium complexes of this type in the Mizoroki-Heck and asymmetric hydroformylation reactions. The related trans-chelating diphosphine WIDEPHOS (Figure 1) was also tested for comparison purposes in the case of the Mizoroki-Heck coupling studies.

\section{Results and Discussion Metal coordination}

As shown previously, HUGPHOS-1 and HUGPHOS-2 are able to accommodate small organometallic moieties, for example the $\mathrm{PdCl}(\mathrm{dmba})$ moiety $\left(\mathrm{dmba}=\mathrm{Me}_{2} \mathrm{NCH}_{2} \mathrm{C}_{6} \mathrm{H}_{4}\right)$, as in complexes 1 [38] and 2 [45] (Scheme 1). In view of the embracing nature of these cavity-shaped ligands, we wondered whether it would be possible to promote the selective formation of monophosphine complexes with $\mathrm{MX}_{2}(\mathrm{M}=\mathrm{Pd}, \mathrm{Pt})$ fragments that normally form $\left[\mathrm{ML}_{2} \mathrm{X}_{2}\right]$ complexes with tertiary phosphines.

When reacted with $\mathrm{HUGPHOS}-1$ in $\mathrm{CH}_{2} \mathrm{Cl}_{2}$, both $\left[\mathrm{PdCl}_{2}(\mathrm{PhCN})_{2}\right]$ and $\left[\mathrm{PtCl}_{2}(\mathrm{PhCN})_{2}\right]$ afforded a mixture of complexes (Scheme 2). The presence of a unique broad signal in each ${ }^{31} \mathrm{P}\left\{{ }^{1} \mathrm{H}\right\}$ NMR spectrum is consistent with the presence of several species in equilibrium. This may reflect exchange processes involving methoxy groups of the primary face and/or free benzonitrile. Mass spectrometric measurements carried out on the crude reaction mixtures showed a peak corresponding to $\mathrm{MCl}_{2}$ (HUGPHOS-1) fragments. There was no indication for the formation of complexes with a molecular weight higher than that of $\left[\mathrm{MCl}_{2}\right.$ (HUGPHOS-1)], this suggesting that no stable bis(phosphine) complexes had formed.

A similar study was carried out with the larger HUGPHOS-2. Its reaction with $\left[\mathrm{PtCl}_{2}(\mathrm{PhCN})_{2}\right]$ in $\mathrm{CH}_{2} \mathrm{Cl}_{2}$ resulted in the formation of the monophosphine complex $\left[\mathrm{PtCl}_{2}\right.$ (HUGPHOS2)(PhCN)] (3) in 95\% yield, but this complex could not be separated from a minor product, probably the benzonitrile-free complex $\left[\mathrm{PtCl}_{2}\right.$ (HUGPHOS-2)]. The ${ }^{31} \mathrm{P}\left\{{ }^{1} \mathrm{H}\right\}$ NMR spectrum of 3 showed a sharp signal at $3.2 \mathrm{ppm}$, with Pt satellites $\left({ }^{1} J_{\mathrm{P}, \mathrm{Pt}}=3433 \mathrm{~Hz}\right)$. The mass spectrum of the mixture of prod-
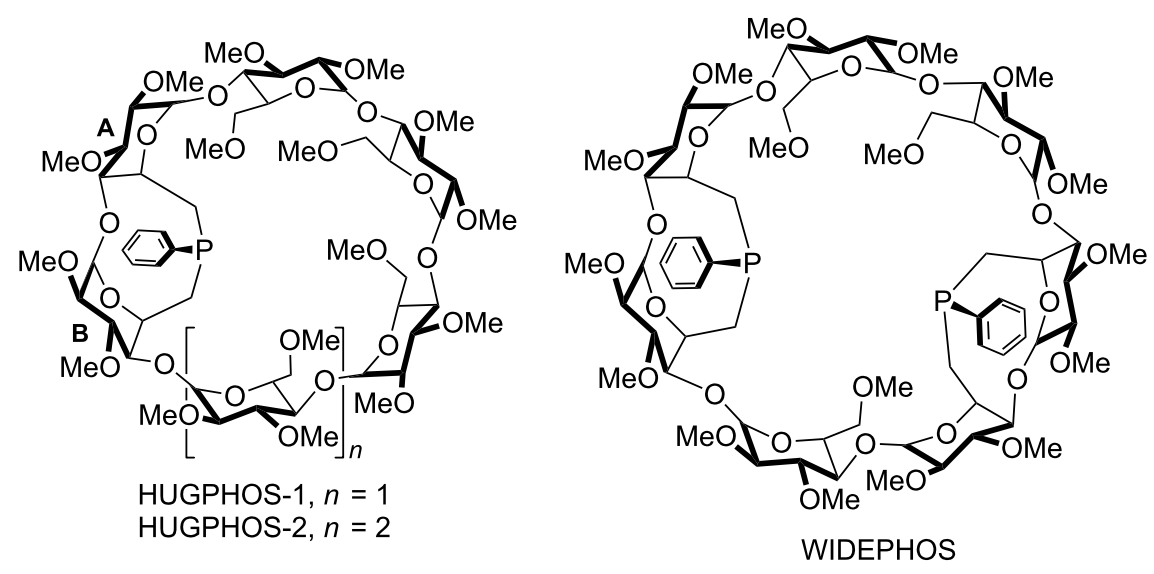

Figure 1: CD-based mono- and diphosphines with inward-pointing phosphorus atoms. 


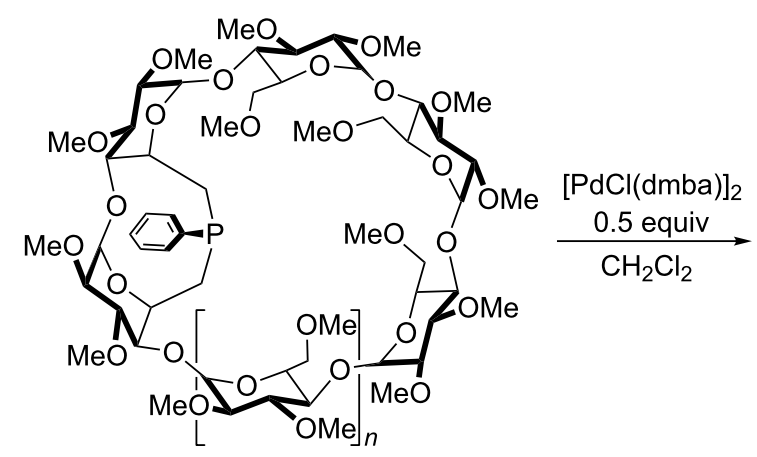

HUGPHOS-1, $n=1$

HUGPHOS-2, $n=2$

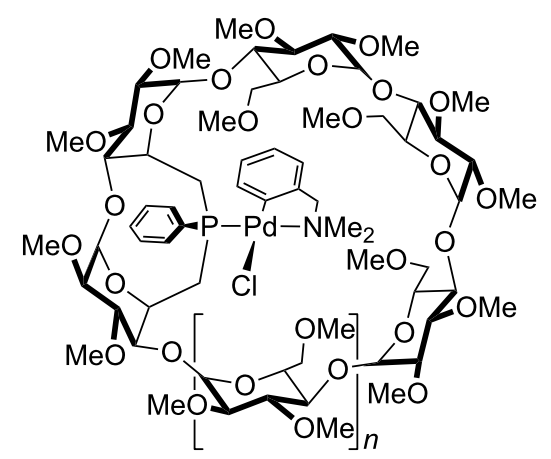

$1, n=1$

2, $n=2$

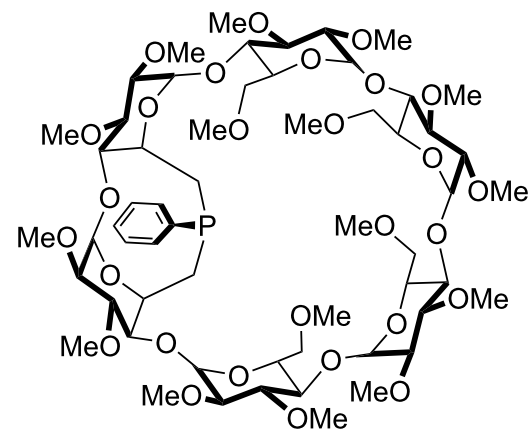

HUGPHOS-1

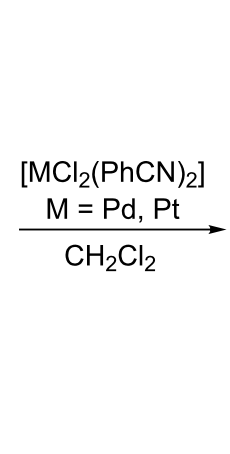

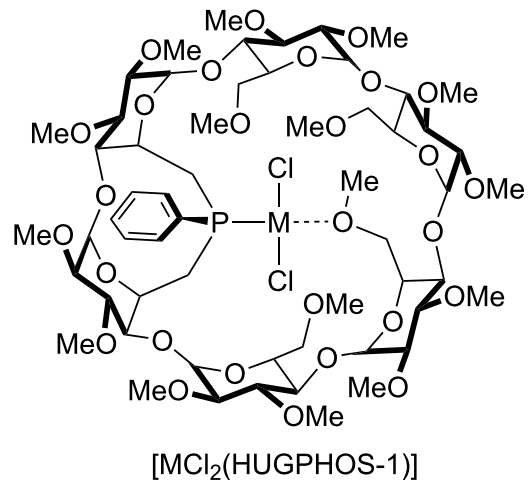

(several isomers in equilibrium)

Scheme 2: Reaction of HUGPHOS-1 with $\left[\mathrm{MCl}_{2}(\mathrm{PhCN})_{2}\right]$ complexes $(\mathrm{M}=\mathrm{Pd}, \mathrm{Pt})$. Only one isomer with a given $\mathrm{MeO}-\mathrm{M}$ bond has been drawn.

ucts showed an intense peak at $m / z=1866.61(100 \%)$, corresponding to the $[\mathrm{M}+\mathrm{Na}]^{+}$cation, as well as a peak resulting from the loss of $\mathrm{PhCN}\left(\mathrm{m} / \mathrm{z}=1763.57\right.$ (11) $\left.[\mathrm{M}-\mathrm{PhCN}+\mathrm{Na}]^{+}\right)$. No peaks corresponding to compounds with two phosphine ligands were detected in the spectrum. Addition of 1 equiv of pyridine to the mixture containing 3 gave quantitatively complex 4 (Scheme 3 ). The ${ }^{1} \mathrm{H}$ NMR spectrum of 4 shows that some H-5 signals are significantly low-field shifted with respect to their counterparts in the free ligand, an observation which is indicative of an entrapped chlorido ligand. Note that the marked affinity of CDs for metal halide bonds is well documented $[46,47]$. The trans $P, N$ configuration was deduced from a ROESY experiment which showed strong correlations between the pyridinic $\mathrm{H}-4$ proton and some inner cavity $\mathrm{H}-5$ protons. Also, a ${ }^{1} J_{\mathrm{P}, \mathrm{Pt}}$ coupling constant typical of this particular geometry $\left({ }^{1} J_{\mathrm{P}, \mathrm{Pt}}=3542 \mathrm{~Hz}\right)$ unequivocally established the configuration of the complex [48].
It should be reminded that monophosphine complexes of the general formula $\left[\mathrm{MX}_{2}\right.$ (phosphine)(pyridine)] usually undergo facile ligand dissociation in solution [48]. This is, however, not the case for complex 4 . Owing to the protecting role played by the cavity, this complex proved to be particularly robust, to such an extent that it could be purified by column chromatography (this being necessary for removing $\mathrm{PhCN}$ ) without noticeable decomposition. Attempts to produce a palladium analogue of $\mathbf{3}$ starting from $\left[\mathrm{PdCl}_{2}(\mathrm{PhCN})_{2}\right]$ failed, the corresponding reaction leading to a mixture of equilibrating species that could not be separated. However, when the reaction mixture was subjected to column chromatography on wet $\mathrm{SiO}_{2}$, a single aqua palladium complex (5) was recovered in high yield (90\%). The P-monoligated nature of this complex was inferred from its mass spectrum, which displays a strong peak at $\mathrm{m} / \mathrm{z}=1675.52$ corresponding to the $[\mathrm{M}+\mathrm{Li}]^{+}$ion. The ${ }^{31} \mathrm{P}\left\{{ }^{1} \mathrm{H}\right\}$ NMR spectrum of 5 revealed a single, slightly broad singlet at 


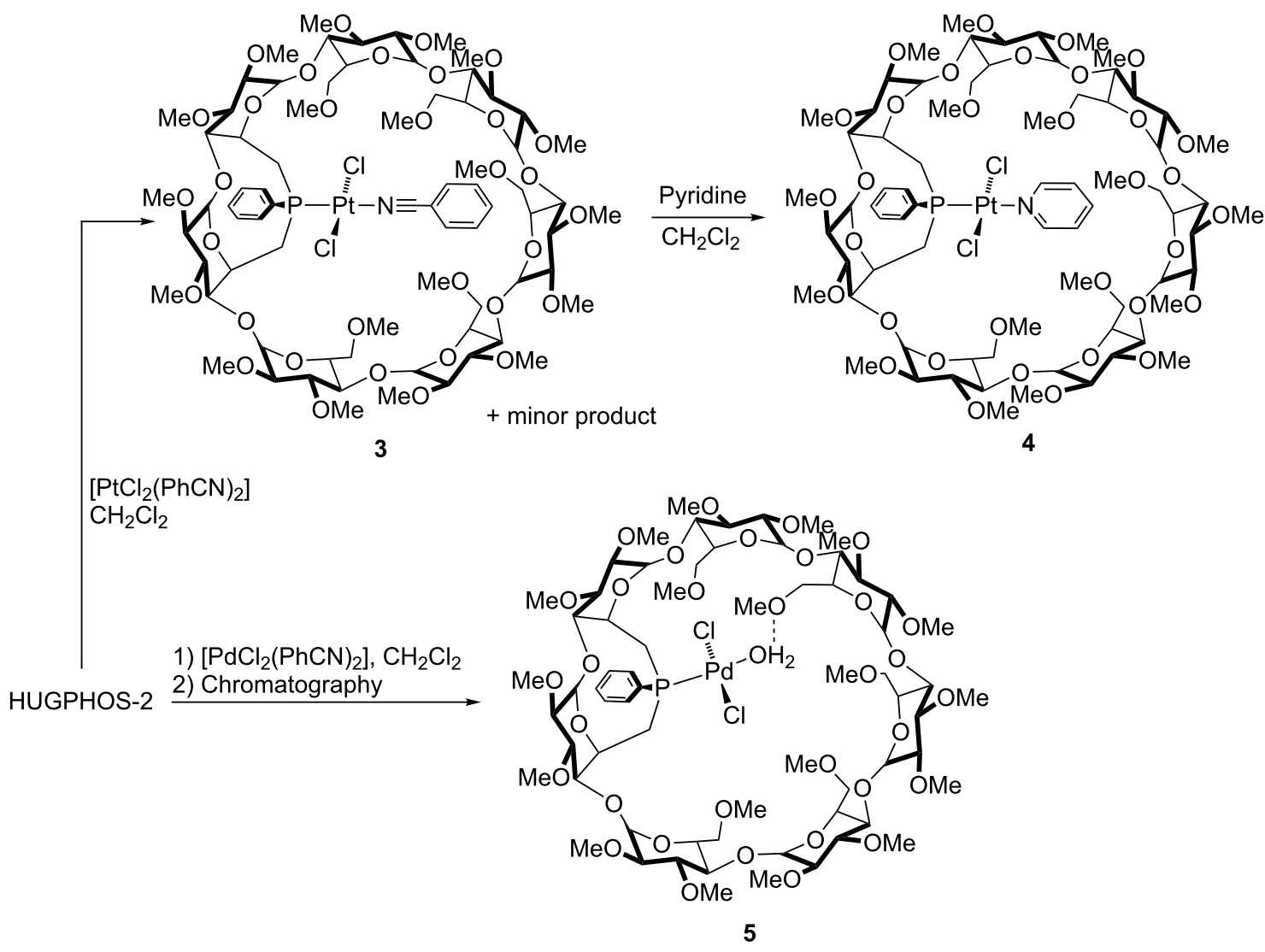

Scheme 3: Synthesis of complexes 3-5

$\delta=34.4 \mathrm{ppm}$. Although not visible at room temperature, the coordinated water molecule appeared as a broad singlet at $\delta=5.64 \mathrm{ppm}$ in the ${ }^{1} \mathrm{H}$ NMR spectrum recorded at $-80{ }^{\circ} \mathrm{C}$ [45] This chemical shift value is typical for aqua palladium complexes [49-51]. A single crystal X-ray diffraction study (Figure 2) confirmed the coordination of a $\left\{\mathrm{PdCl}_{2}\left(\mathrm{H}_{2} \mathrm{O}\right)\right\}$ fragment, which lies inside the $\beta$-CD cavity. To date, only one other example of $\left[\mathrm{MCl}_{2}\right.$ (phosphine) $\left.\left(\mathrm{H}_{2} \mathrm{O}\right)\right]$ aqua complex has been reported [52].

Complex 5 could be dehydrated using a Dean-Stark apparatus to give the corresponding methoxy-bonded complex 6 (Scheme 4). The mass spectrum of $\mathbf{6}$ shows a strong peak at $m / z=1673.52$ having the isotopic profile expected for the $[\mathrm{M}+\mathrm{Na}]^{+}$ion. The ${ }^{1} \mathrm{H}$ NMR spectra of $\mathbf{5}$ and $\mathbf{6}$ are very similar, however small differences could be detected, in particular in the chemical shift range where methoxy protons resonate. Although it was not possible to determine which methoxy group was bonded to the metal centre because of overlapping signals, coordination of the one belonging to glucose unit $\mathrm{G}$ seems to be the most likely according to CPK models. Also, the anomeric protons of 6 lie in a wider range $(\Delta \delta=0.36 \mathrm{ppm})$ than those of less distorted $5(\Delta \delta=0.18 \mathrm{ppm})$. Note that complex 5 is readily reformed in the presence of water.

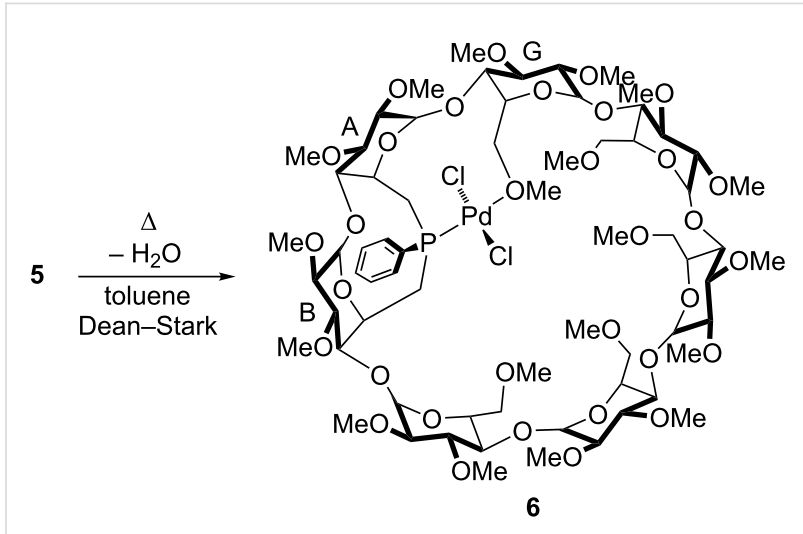

Scheme 4: Dehydration of Pd(II) complex 5.

HUGPHOS-2 was further opposed to $\left[\mathrm{RuCl}_{2} \text { (p-cymene) }\right]_{2}$. This reaction gave a 57:43 mixture of the two rotamers 7 and $\mathbf{8}$, which could be separated by column chromatography (Figure 3). Careful examination of the ROESY spectrum of 7 


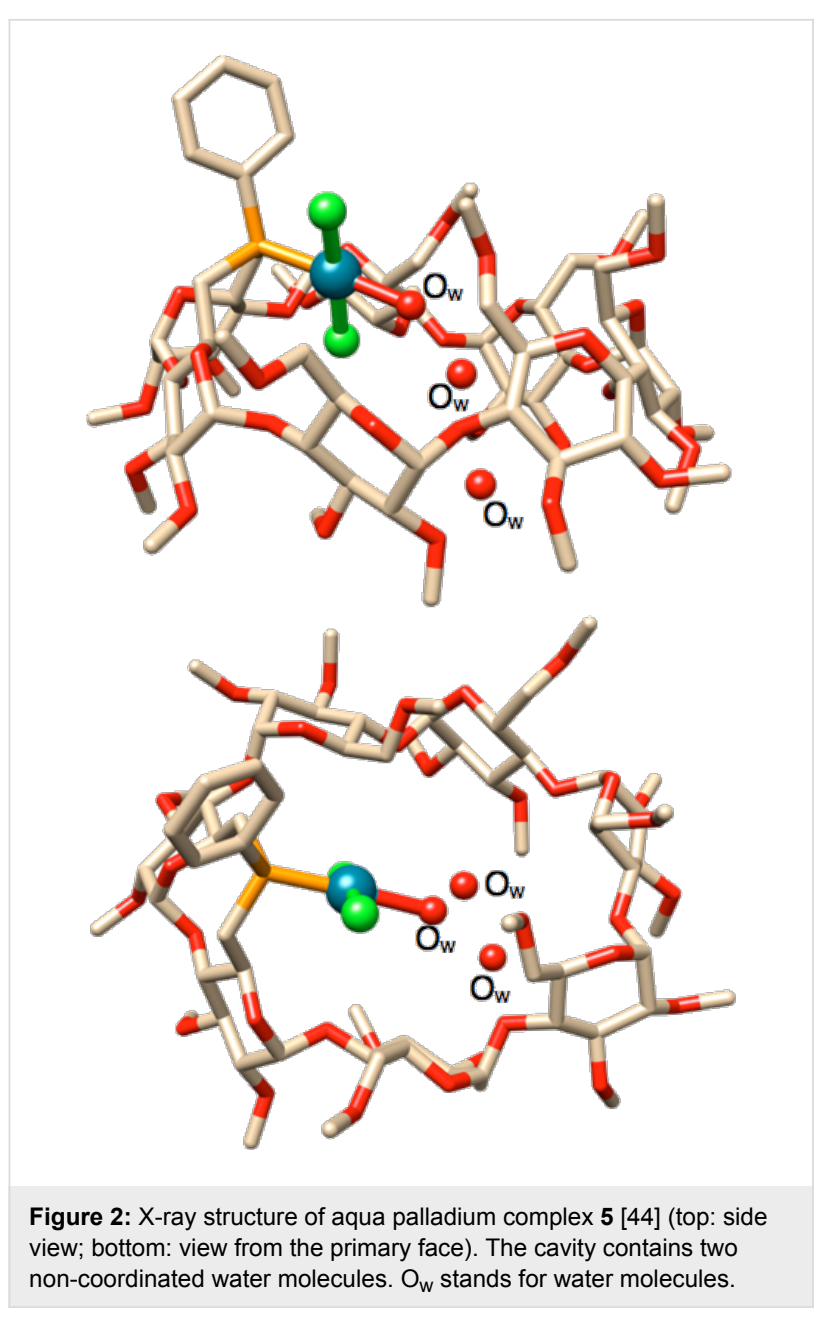

indicates that the rotations about the $\mathrm{P}-\mathrm{Ru}$ bond and the $\mathrm{Ru}$-arene bond are both restricted. Thus, the ROESY spectrum of this complex showed correlations between the Me group of the $p$-cymene ligand and protons belonging to glucose units $\mathrm{G}$
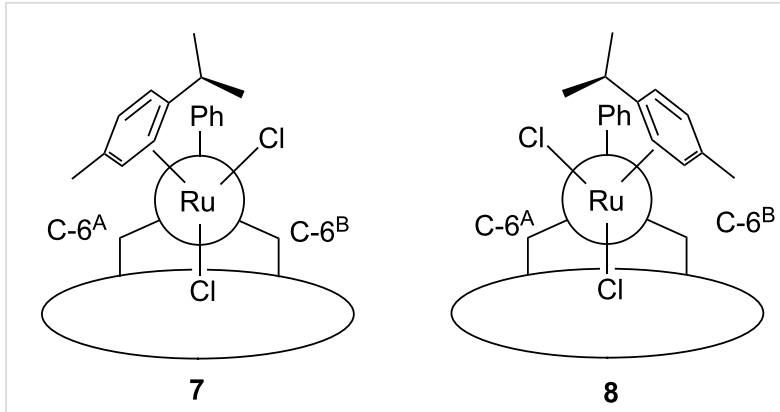

Figure 3: Ruthenium complexes $\mathbf{7}$ and $\mathbf{8}$ in Newman projection along the Ru-P bond.

and $\mathrm{A}$, but not with protons from the $\mathrm{PPh}$ ring or glucose units $\mathrm{B}$ and $\mathrm{C}$. In keeping with these findings, the only cross peaks associated with the $\mathrm{CHMe}$, proton of 7 involved protons from the $\mathrm{PPh}$ ring. Similar observations, which establish the same blocked rotations about the $\mathrm{P}-\mathrm{Ru}$ and the $\mathrm{Ru}-$ arene bonds were made for $\mathbf{8}$. It should be emphasised that prolonged heating of 7 in refluxing toluene did not result in the formation of $\mathbf{8}$. Restricted rotation about the $\mathrm{Ru}-\mathrm{P}$ bond in $\mathbf{7}$ is possibly caused by the entrapment of one of the chlorido ligands inside the cavity.

Further proof for the capacity of HUGPHOS-1 to prevent the formation of bis(phosphine) complexes came from the reaction of $\left[\mathrm{RhCl}(\mathrm{CO})_{2}\right]_{2}$ with excess ligand, which only produced cis[RhCl(HUGPHOS-1)(CO) 2 (9) together with free phosphine, rather than the expected complex trans-[RhCl(HUGPHOS1) $2(\mathrm{CO})]$ (Figure 4, Scheme 5). The corresponding IR spectrum is typical of $\mathrm{CO}$ ligands in relative cis positions (strong $\mathrm{CO}$ bands at 2009 and $2082 \mathrm{~cm}^{-1}$ ). Further, with some CD H-5 protons belonging to non-bridged glucose units strongly upfield shifted upon metal complexation ( $\Delta \delta$ up to $0.7 \mathrm{ppm}$ ), the

\section{HUGPHOS-1 in $\mathrm{CDCl}_{3}$}

HUGPHOS-1 + 0.25 equiv $\left[\mathrm{Rh}(\mathrm{CO})_{2} \mathrm{Cl}\right]_{2}(\mathrm{P} / \mathrm{Rh} 2: 1)$ in $\mathrm{CDCl}_{3}$

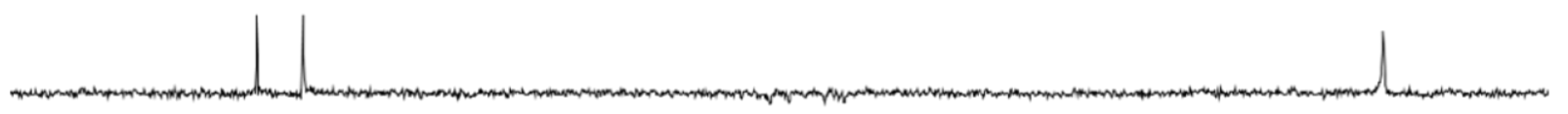

HUGPHOS- $1+0.5$ equiv $\left[\mathrm{Rh}(\mathrm{CO})_{2} \mathrm{Cl}\right]_{2}(\mathrm{P} / \mathrm{Rh} 1: 1)$ in $\mathrm{CDCl}_{3}$

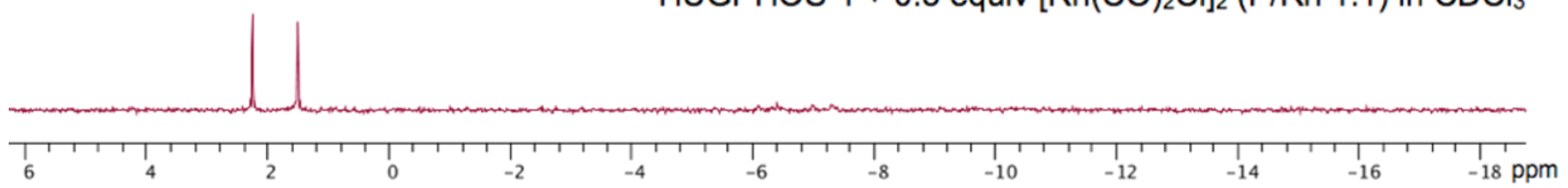

Figure 4: Titration of HUGPHOS-1 with $\left[\mathrm{Rh}(\mathrm{CO})_{2} \mathrm{Cl}\right]_{2}$ at $25^{\circ} \mathrm{C}$. 


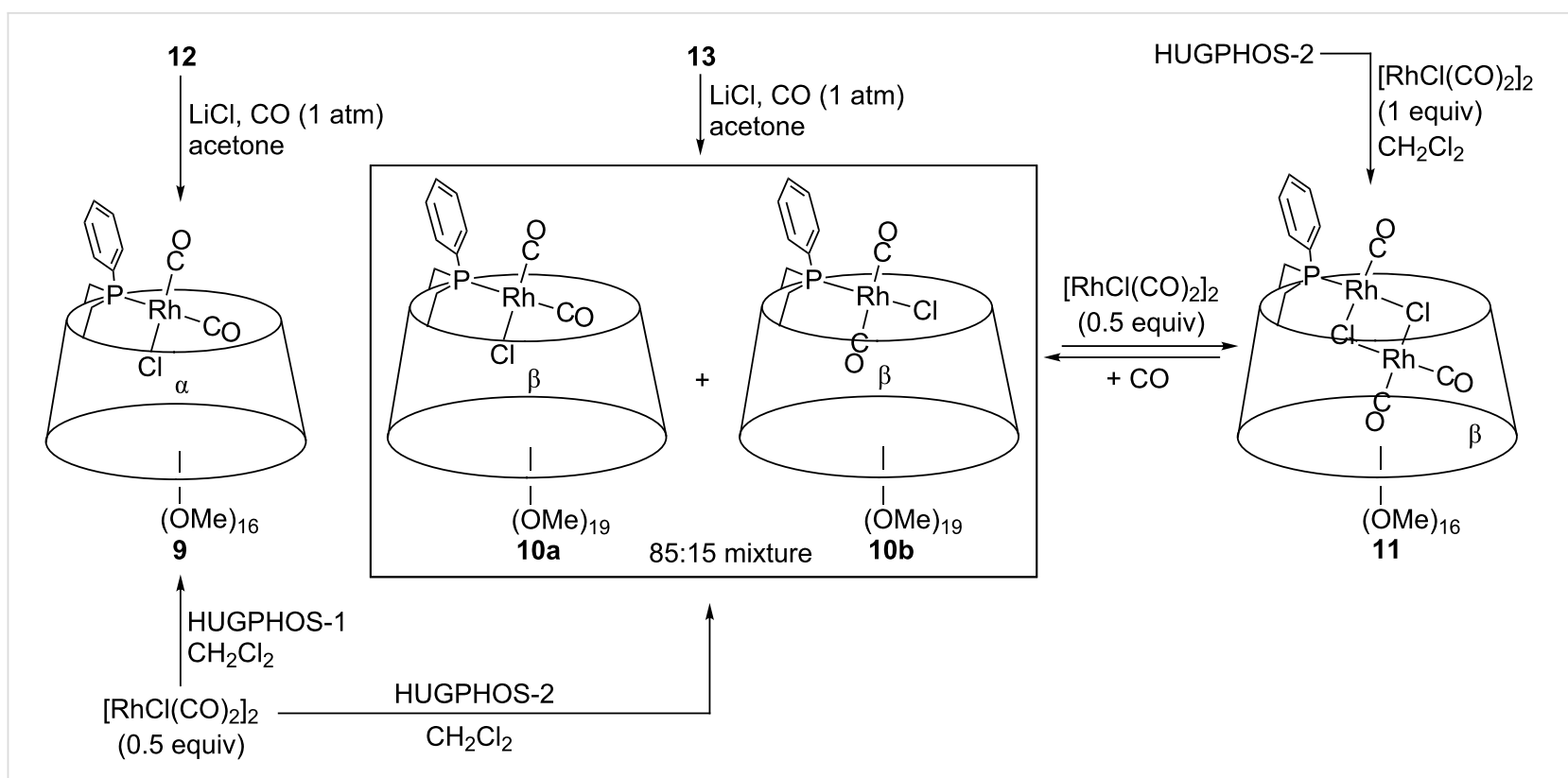

Scheme 5: Synthesis of rhodium carbonyl complexes 9-11.

${ }^{1} \mathrm{H}$ NMR spectrum of 9 is fully consistent with a CD-encapsulated chlorido ligand [53], which can only mean that two cis configured CO ligands are present [22].

In the case of HUGPHOS-2, the reaction with 0.5 equiv of $\left[\mathrm{RhCl}(\mathrm{CO})_{2}\right]_{2}$ resulted in the formation of an $85: 15$ mixture of the inseparable, mononuclear stereoisomeric complexes 10a and 10b (Scheme 5), in which the two CO ligands are respectively cis (strong CO IR bands at 2009 and $2082 \mathrm{~cm}^{-1}$ [54]) and trans (strong CO IR band at $1985 \mathrm{~cm}^{-1}[55,56]$ ) configured. Remarkably, the same ratio of stereoisomers was obtained when

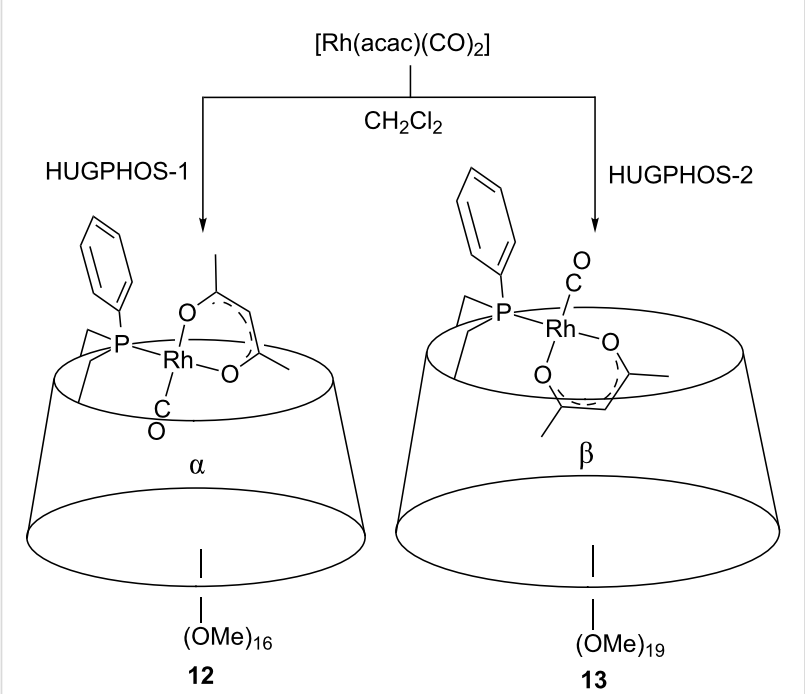

Scheme 6: Synthesis of rhodium complexes 12 and 13. rhodium complex 13 (see Scheme 6) was treated with $\mathrm{LiCl}$ under $\mathrm{CO}(1 \mathrm{~atm})$. When the reaction between HUGPHOS-2 and $\left[\mathrm{RhCl}(\mathrm{CO})_{2}\right]_{2}$ was repeated, but applying a 1:1 instead of 1:0.5 stoichiometry, the dinuclear complex $\left[\mathrm{Rh}_{2}(\mu\right.$ $\left.\mathrm{Cl})_{2}(\mathrm{HUGPHOS}-2)(\mathrm{CO})_{3}\right]$ (11) formed (see Experimental part). Clearly, the cavity of HUGPHOS-2 is capable of accommodating up to two metal centres, whereas the smaller HUGPHOS-1 ligand is unable to do so.

The HUGPHOS ligands were further reacted with $\left[\mathrm{Rh}(\mathrm{acac})(\mathrm{CO})_{2}\right]($ acac $=$ acetylacetonate $)$, this producing quantitatively the singly P-ligated rhodium complexes $\mathbf{1 2}$ and 13 (Scheme 6). While in $\mathbf{1 3}$ the large $\beta$-CD cavity hosts the acac ligand, the same ligand is located outside the $\alpha-C D$ cavity in $\mathbf{1 2}$ according to ROESY experiments. On the other hand, the smaller CO rod is nested in the $\alpha$-CD cavity of $\mathbf{1 2}$, and located outside the $\beta$-CD cavity in $\mathbf{1 3}$. Clearly, size selectivity is at work in these metal complexes. As already observed for complex 4, both 12 and 13 are remarkably stable and can be purified by column chromatography on $\mathrm{SiO}_{2}$. This makes them, a priori, good candidates for hydroformylation studies.

\section{High-pressure NMR studies}

Upon subjecting complex 13 to a syngas $\left(1: 1 \mathrm{CO} / \mathrm{H}_{2}\right.$ mixture) pressure of 40 bar at $80{ }^{\circ} \mathrm{C}$ in toluene- $d_{8}$ (Scheme 7), the only species that was detected by high-pressure NMR and IR spectroscopy [44] was complex trans-[RhH(HUGPHOS-2)(CO) 3 ] (14). Confirmation of a 5-coordinate rhodium centre in $\mathbf{1 4}$ came from MS measurements carried out from the toluene- $d_{8}$ solution, which showed the presence of a peak at $1663.53(1 \%$, 


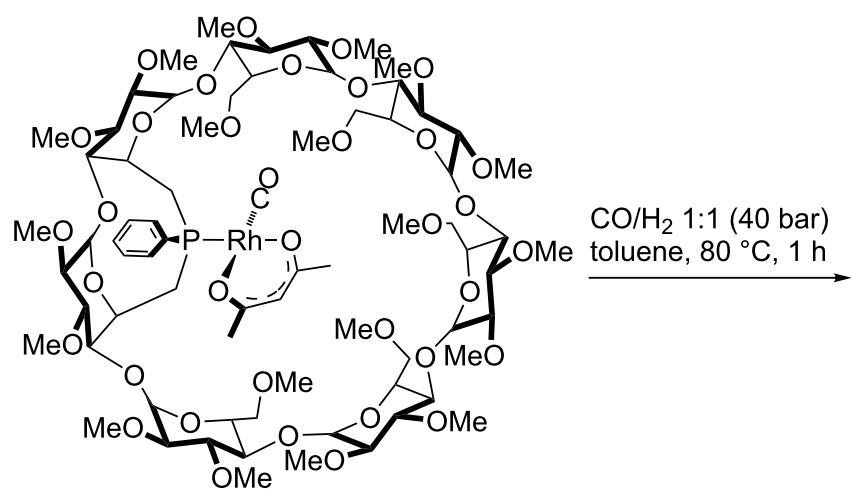

13

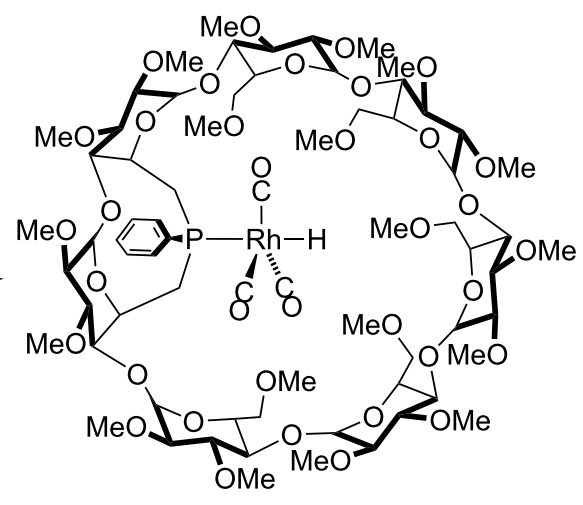

14

Scheme 7: Selective formation of complex 14 under 40 bar $\mathrm{CO} / \mathrm{H}_{2}$ at $80^{\circ} \mathrm{C}$.

exact isotopic profile) corresponding to the expected $[\mathrm{M}+\mathrm{H}]^{+}$ ion.

The ${ }^{31} \mathrm{P}\left\{{ }^{1} \mathrm{H}\right\}$ NMR spectrum of $\mathbf{1 4}$ consisted of a doublet at $28.1 \mathrm{ppm}\left({ }^{1} J_{\mathrm{P}, \mathrm{Rh}}=95 \mathrm{~Hz}\right)$. The presence of a hydride ligand trans to the $\mathrm{P}$ atom was inferred from the ${ }^{1} \mathrm{H}$ NMR spectrum of $14\left(25{ }^{\circ} \mathrm{C}, 40 \mathrm{bar}\right)$, which displays a signal at $-8.8 \mathrm{ppm}$ $\left({ }^{1} J_{\mathrm{H}, \mathrm{Rh}}=6.2 \mathrm{~Hz}\right)$ with a large ${ }^{2} J(\mathrm{H}, \mathrm{P})$ coupling constant $\left({ }^{2} J_{\mathrm{H}, \mathrm{P}}=103 \mathrm{~Hz}\right)$ (Figure 5). The three close together carbonyl bands at 1982 (vs), 1989 (vs), and 1992 (sh, vs) $\mathrm{cm}^{-1}$ and the

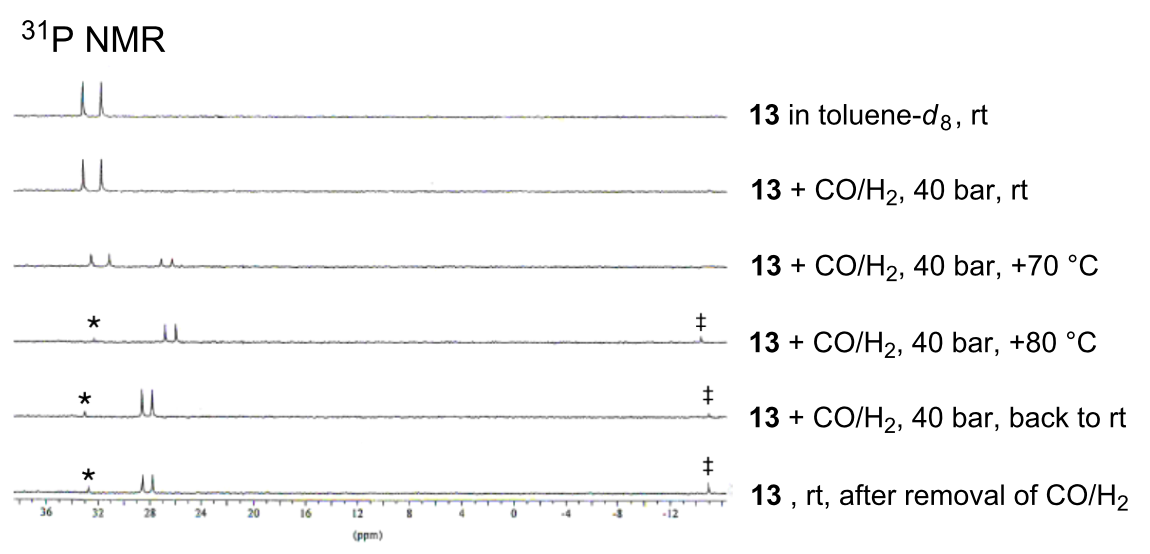

${ }^{1} \mathrm{H}$ NMR (hydride region)

13 in toluene- $d_{8}, \mathrm{rt}$

$13+\mathrm{CO} / \mathrm{H}_{2}, 40$ bar, rt

$13+\mathrm{CO} / \mathrm{H}_{2}, 40$ bar, $+70{ }^{\circ} \mathrm{C}$

$13+\mathrm{CO} / \mathrm{H}_{2}, 40$ bar, $+80{ }^{\circ} \mathrm{C}$

$13+\mathrm{CO} / \mathrm{H}_{2}, 40$ bar, back to $\mathrm{rt}$

13 , rt, after removal of $\mathrm{CO} / \mathrm{H}_{2}$ 


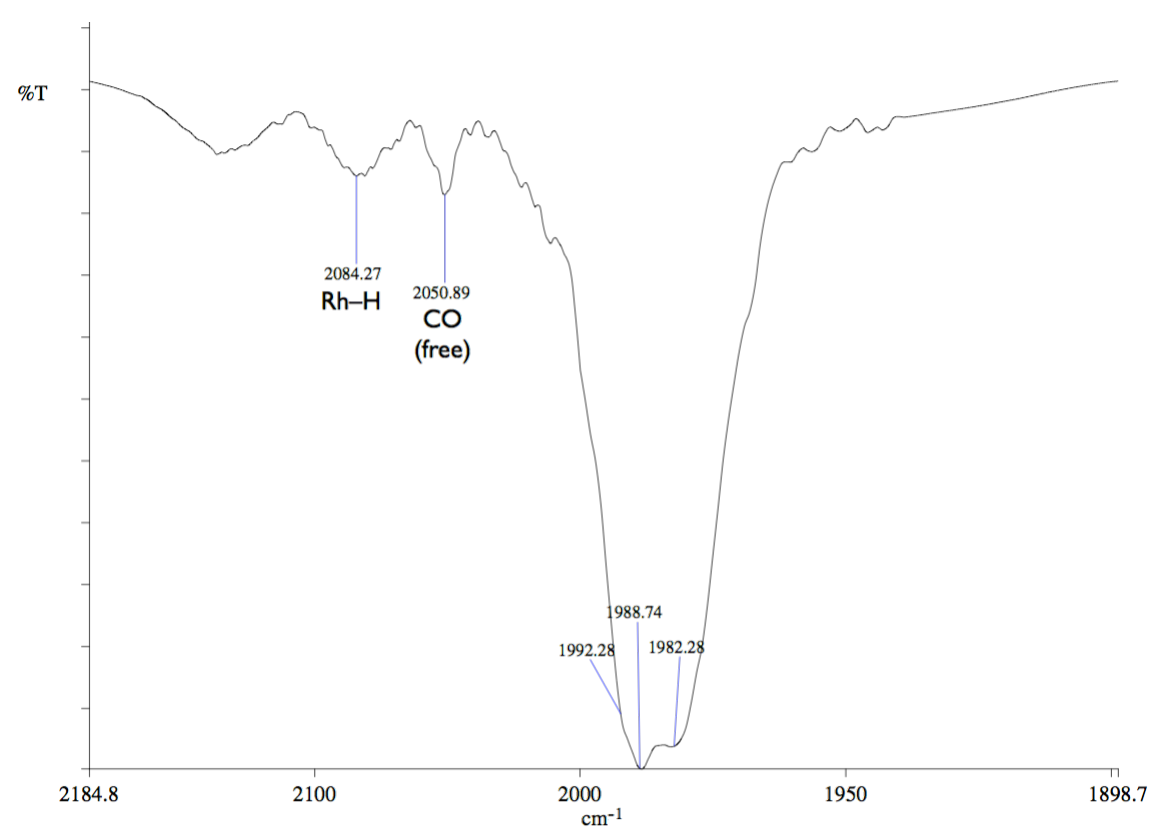

Figure 6: IR spectra of 14 recorded in $\mathrm{CH}_{2} \mathrm{Cl}_{2}$ at $50{ }^{\circ} \mathrm{C}$ under 40 bar of $\mathrm{CO} / \mathrm{H}_{2}$ 1:1.

additional $\mathrm{Rh}-\mathrm{H}$ broad band of low intensity at $2084 \mathrm{~cm}^{-1}$ (Figure 6) in the IR spectrum of 14 measured at $50{ }^{\circ} \mathrm{C}$ under 40 bar of $\mathrm{CO} / \mathrm{H}_{2}$ are consistent with a trigonal bipyramidal complex having $C_{1}$ symmetry.

The carbonyl region of the IR spectrum of $\mathbf{1 3}$ markedly differs from that of the only other reported trans- $\left[\mathrm{RhH}(\mathrm{CO})_{3} \mathrm{~L}\right]$ complex (where $\mathrm{L}$ is a bulky phosphoramidite), the observed three carbonyl bands (2055 (sh), 2022 (w) and $1998(\mathrm{~s}) \mathrm{cm}^{-1}$ ) being here spread over a larger frequency range [31]. Note that the related cobalt complex trans- $\left[\mathrm{CoH}(\mathrm{CO})_{3}\left(\mathrm{PCy}_{3}\right)\right]$ displays a higher symmetry $\left(D_{3 \mathrm{~h}}\right)$, and accordingly, its IR spectrum shows only one carbonyl band [57-60].

The phosphorus atom in $\mathbf{1 4}$ probably binds the rhodium centre specifically in an apical fashion because of the confining properties of the phosphine. In fact, the trigonal bipyramidal complex has no other option, but to adopt a linear $\mathrm{P}-\mathrm{Rh}-\mathrm{H}$ arrangement (Figure 7), so that steric interactions between the carbonyl ligands and the cavity inner wall are reduced to the maximum.

\section{Hydroformylation of styrene}

The results of the above HP-NMR studies prompted us to investigate the properties of HUGPHOS ligands in an asymmetric hydroformylation [33-37]. Styrene was chosen as this substrate is compatible in terms of size with both $\mathrm{CD}$ cavities. Five different parameters, namely temperature, pressure, $\mathrm{CO} / \mathrm{H}_{2}$ and $\mathrm{L} / \mathrm{Rh}$ ratios as well as pre-catalyst loadings were varied

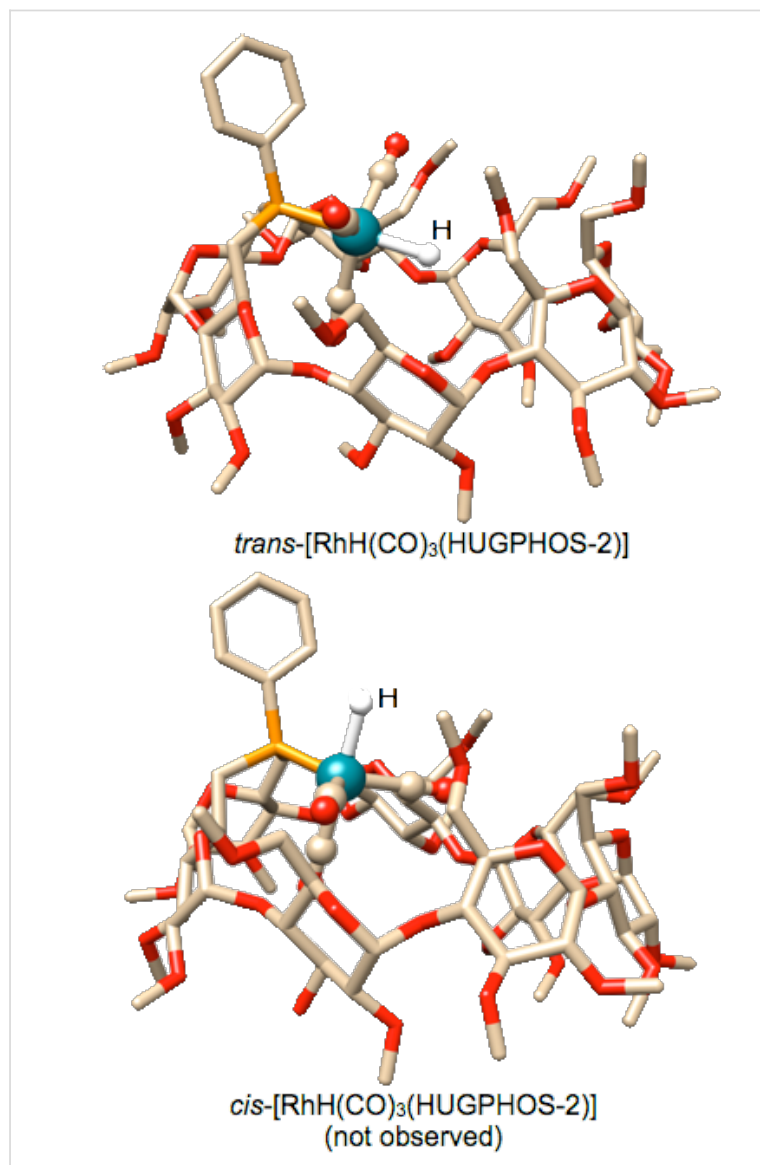

Figure 7: Calculated structures (Spartan 10) of trigonal bipyramidal $\left[\mathrm{RhH}(\mathrm{CO})_{3}(\mathrm{HUGPHOS}-2)\right]$ with the phosphorus being either in apical (top) or equatorial (bottom) position. 
during the catalytic study (Table 1 and Table 2). When standard hydroformylation conditions (Table 1, entry 1) were applied, next to full conversion was observed after $24 \mathrm{~h}$ with $\mathbf{1 3}$. As expected, the branched product was formed predominantly, however with poor enantioselectivity. Surprisingly, raising the $\mathrm{CO} / \mathrm{H}_{2}$ from $1: 1$ to $1: 2$, which is known to speed up the reaction, produced the opposite effect and was also detrimental to enantioselectivity [22], but without significantly altering regioselectivity (Table 1, entry 2). On the other hand, increasing the partial CO pressure led to a marked reaction rate increase, however with neither enantioselectivity, nor regioselectivity increase (Table 1, entry 3). An unexpected observation was that addition of free ligand to the reaction medium maintained at $80{ }^{\circ} \mathrm{C}$ (20 bar) was detrimental to the catalyst activity, this suggesting that at this temperature unreactive bis(phosphine) complexes formed (Table 1, entries 4 and 5), although for HUGPHOS ligands bis(phosphine) complexes have never been isolated so far.

Raising the temperature to $120^{\circ} \mathrm{C}$ caused the catalyst activity to drop significantly and led predominantly to the $(S)$-enantiomer, suggesting a profound transformation of the catalyst upon heating (Table 2, entry 2). However, both regioselectivity and enantioselectivity improved significantly upon lowering the

Table 1: Rhodium-catalysed hydroformylation of styrene using precatalyst 13 - variation of ligand/Rh and $\mathrm{CO} / \mathrm{H}_{2}$ ratio. ${ }^{\mathrm{a}}$

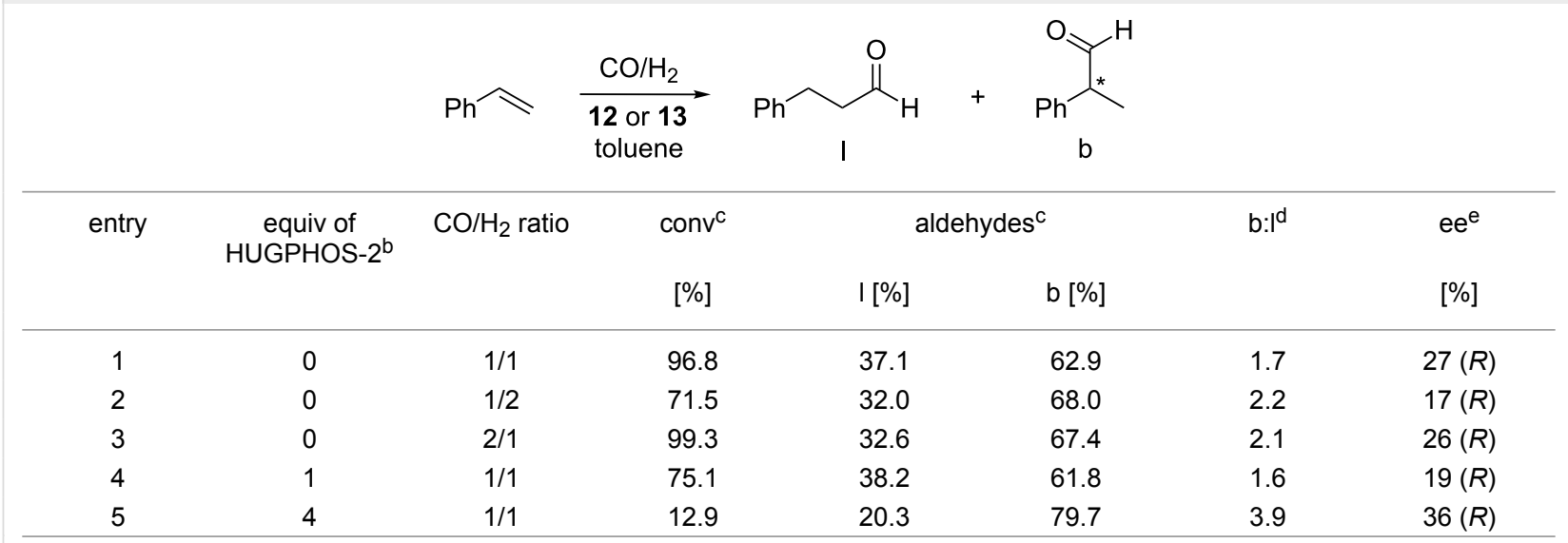

a Styrene $(5 \mathrm{mmol})$, styrene/complex $=2500, T=80^{\circ} \mathrm{C}, t=24 \mathrm{~h}, P\left(\mathrm{CO} / \mathrm{H}_{2}\right)=20$ bar, toluene $/ n$-decane $(15 \mathrm{~mL} / 0.5 \mathrm{~mL})$, incubation overnight at $80{ }^{\circ} \mathrm{C}$ under $P\left(\mathrm{CO} / \mathrm{H}_{2}\right)=20$ bar. bquiv of free ligand HUGPHOS-2 added to preformed rhodium complex 13 after overnight incubation. ${ }^{\mathrm{C}} \mathrm{Determined} \mathrm{by} \mathrm{GC}$ using decane as internal standard. ${ }^{\mathrm{d}} \mathrm{b}: \mathrm{I}$ (branched:linear) aldehyde ratio. ${ }^{\mathrm{e}}$ Determined by chiral-phase $\mathrm{GC}$ after reduction with $\mathrm{LiAlH}_{4}$.

Table 2: Rhodium-catalysed hydroformylation of styrene using precatalysts 12 and 13 - variation of pressure and temperature. ${ }^{a}$

\begin{tabular}{|c|c|c|c|c|c|c|c|c|}
\hline \multirow[t]{2}{*}{ entry } & \multirow[t]{2}{*}{ complex } & \multirow{2}{*}{$\begin{array}{c}P\left(\mathrm{CO} / \mathrm{H}_{2}\right)^{\mathrm{b}} \\
{[\text { bar }]}\end{array}$} & \multirow{2}{*}{$\begin{array}{c}T \\
{\left[{ }^{\circ} \mathrm{C}\right]}\end{array}$} & \multirow{2}{*}{$\begin{array}{c}\text { conv }^{c} \\
{[\%]}\end{array}$} & \multicolumn{2}{|c|}{ aldehydes $^{c}$} & \multirow[t]{2}{*}{$b / l^{d}$} & \multirow{2}{*}{$\begin{array}{l}e^{e} \\
{[\%]}\end{array}$} \\
\hline & & & & & I [\%] & $\mathrm{b}[\%]$ & & \\
\hline 1 & 13 & 20 & 80 & 96.8 & 37.1 & 62.9 & 1.7 & $27(R)$ \\
\hline 2 & 13 & 20 & 120 & 31.5 & 43.0 & 57.0 & 1.3 & $34(S)$ \\
\hline 3 & 13 & 20 & 60 & 43.7 & 13.9 & 86.1 & 6.2 & $63(R)$ \\
\hline $4^{f}$ & 13 & 20 & 40 & 79.0 & 6.8 & 93.2 & 13.7 & $80(R)$ \\
\hline $5^{f}$ & 13 & 40 & 20 & 66.2 & 1.7 & 98.3 & 57.8 & $92(R)$ \\
\hline 6 & 12 & 20 & 80 & 86.3 & 27.2 & 72.8 & 2.7 & $33(R)$ \\
\hline $7^{f}$ & 12 & 20 & 60 & 100 & 11.4 & 88.6 & 7.8 & $62(R)$ \\
\hline $8^{f}$ & 12 & 20 & 40 & 99.8 & 6.3 & 93.7 & 14.9 & $80(R)$ \\
\hline $9^{f}$ & 12 & 20 & 20 & 30.6 & 1.0 & 99.0 & 99.0 & $93(R)$ \\
\hline $10^{f}$ & 12 & 5 & 40 & 19.8 & 21.4 & 78.6 & 3.7 & $41(R)$ \\
\hline $11^{f}$ & 12 & 40 & 40 & 99.2 & 3.9 & 96.1 & 24.6 & $90(R)$ \\
\hline $12^{f}$ & 12 & 40 & 20 & 60.7 & 1.7 & 98.3 & 57.8 & $95(R)$ \\
\hline $13^{f}$ & 12 & 40 & 4 & 34.0 & traces & 100 & $>100^{g}$ & $93(R)$ \\
\hline
\end{tabular}

astyrene $(5 \mathrm{mmol})$, styrene/complex $=2500, t=24 \mathrm{~h}$, toluene $/ n$-decane $(15 \mathrm{~mL} / 0.5 \mathrm{~mL})$, incubation overnight at $80{ }^{\circ} \mathrm{C}$ under $P\left(\mathrm{CO} / \mathrm{H}_{2}\right)=20$ bar. ${ }^{\mathrm{b}} \mathrm{CO} / \mathrm{H}_{2} 1: 1 \mathrm{v} / \mathrm{v}$. ${ }^{\mathrm{c} D e t e r m i n e d ~ b y ~ G C ~ u s i n g ~ d e c a n e ~ a s ~ i n t e r n a l ~ s t a n d a r d . ~}{ }^{\mathrm{d}} \mathrm{b}: \mathrm{l}$ aldehyde ratio. ${ }^{e}$ Determined by chiral-phase $\mathrm{GC}$ after reduction with

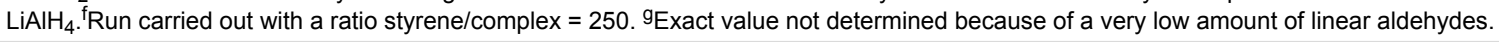


temperature, reaching $63 \%$ ee at $60{ }^{\circ} \mathrm{C}$ (Table 2 , entry 3 ). Increasing the metal to substrate ratio by 10 -fold and further lowering the temperature allowed to maintain a reasonable activity while further increasing the ee value and $b: 1$ ratio (Table 2, entry 4). Interestingly, complexes 12 and $\mathbf{1 3}$ led roughly to the same results (Table 2, entries 5 and 12). This means that the reaction is insensitive to cavity size, this being indicative of a catalytic transformation taking place at the cavity entrance, rather than inside. Pressure had also a dramatic effect on both regioselectivity and enantioselectivity as raising it from 5 to 40 bar increased the ee value by a staggering $49 \%$ and the b:1 ratio from 3.7 to 24.6 (Table 2, entries 10 and 11). Not surprisingly, the best result (Table 2, entry 12) was obtained at room temperature and high pressure, the ee value and the proportion of branched aldehyde reaching then $95 \%$ and $98.3 \%$, respectively.

Clearly, isoregioselectivity increases concomitantly with enantioselectivity contrary to what is generally observed [37], probably because the singly phosphine-ligated active species behaves differently from the usual bis(phosphine) complexes (Scheme 8). The observed enantio- and isoregioselectivities are amongst the highest reported for the asymmetric hydroformylation of styrene [61-63]. The presence of monophosphine intermediates (and not bis(phosphine) ones) in the catalytic cycle is likely to favour the formation of a $\left[\mathrm{Rh}\left(\eta^{3}\right.\right.$-(styrenyl $\left.\left.)\right)(\mathrm{CO})_{2}\right]$ intermediate [31,32,37], precursor of the branched aldehyde, over that of the electron poorer $\left[\mathrm{Rh}(\sigma-(\right.$ phenylethyl $\left.))(\mathrm{CO})_{2}\right]$ isomer, which leads to the linear aldehyde. The high enantioselectivities probably arise from the embracing properties of the HUGPHOS ligands, which facilitates chirality transfer.

\section{Heck cross-coupling}

Phosphine-assisted Heck reactions strongly depend on the bulkiness of the phosphine used [64]. To assess HUGPHOS-2 in Heck coupling, we focused on the reaction between styrene and aryl bromides using $\left[\mathrm{Pd}(\mathrm{OAc})_{2}\right](\mathrm{OAc}=$ acetate $)$ as a palladium source [65]. In a preliminary study, 4-bromoanisole was reacted
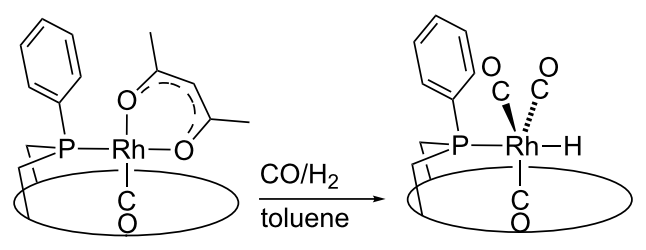

12 or 13
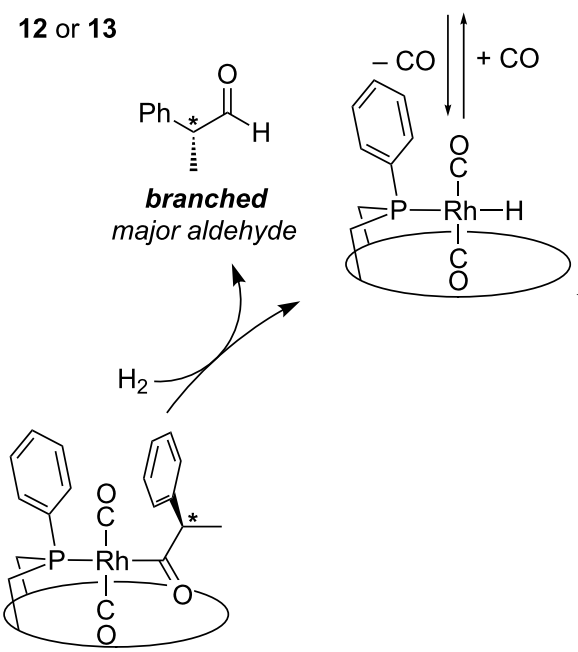<smiles>C=Cc1ccccc1</smiles>
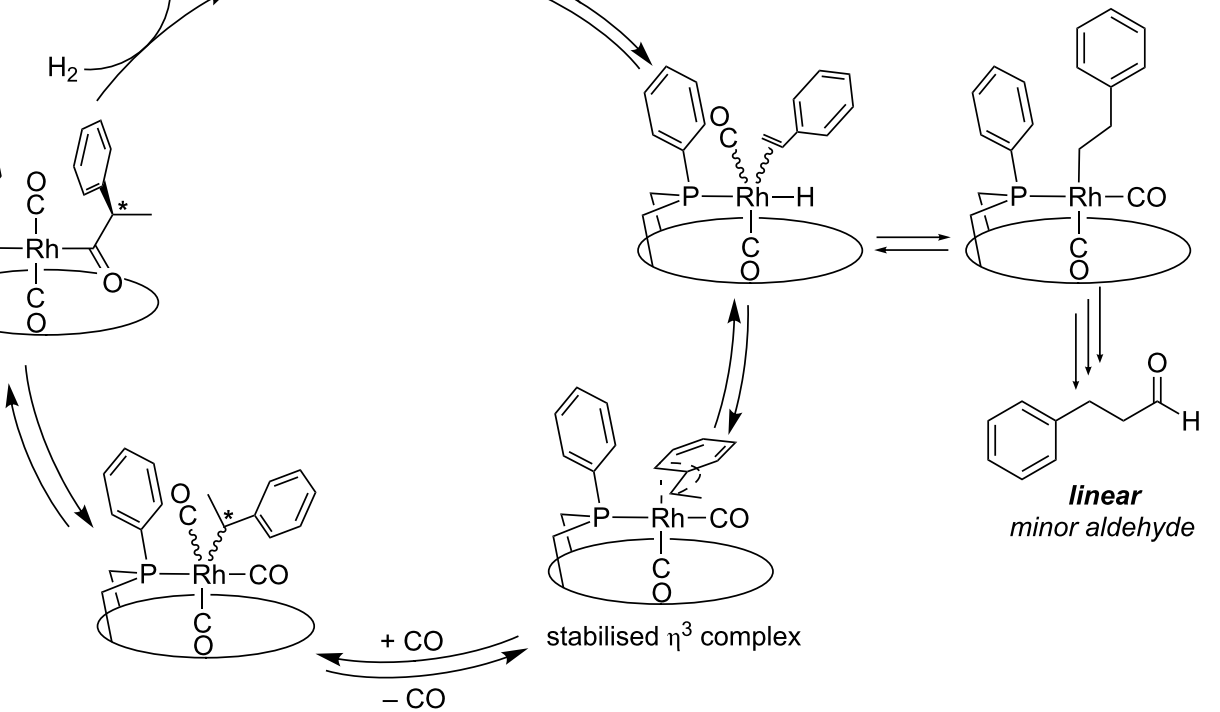

Scheme 8: Possible mechanism for the hydroformylation of styrene when using monophosphine complexes 12 or 13 as precatalysts. 
Table 3: Optimisation of conditions for the Heck cross-coupling of 4-bromoanisole with styrene using HUGPHOS-2 as ligand. ${ }^{a}$

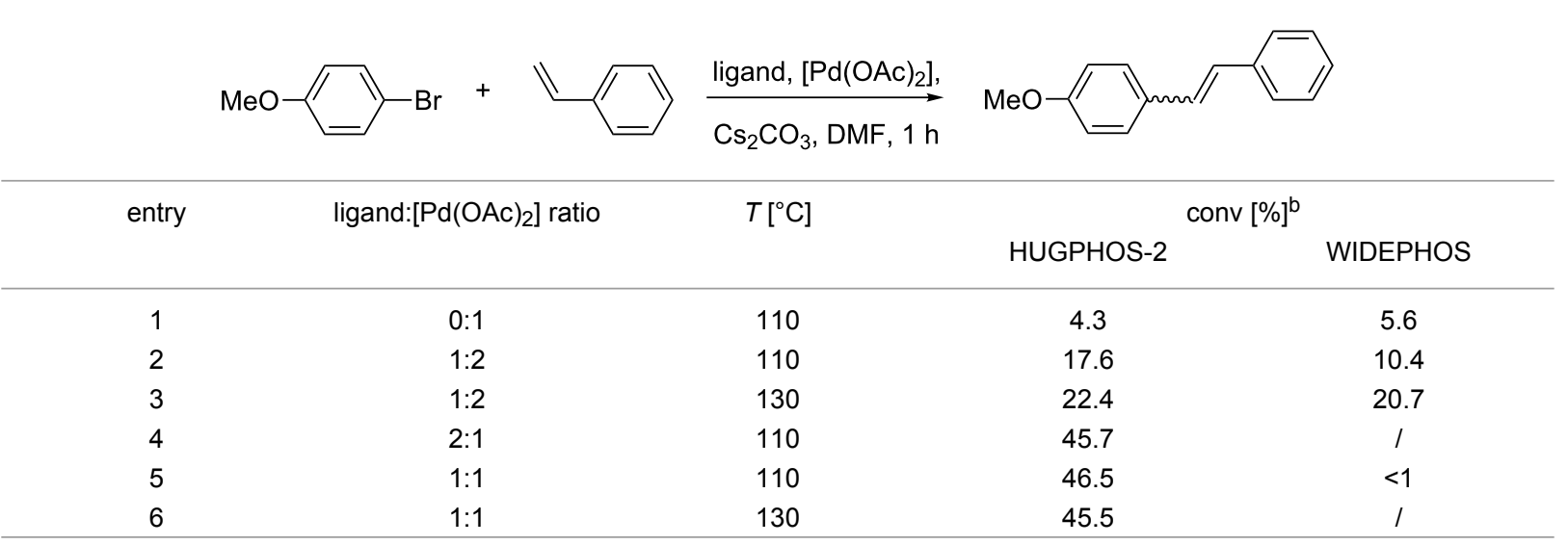

a $\left.\mathrm{Pd}(\mathrm{OAc})_{2}\right]\left(5 \times 10^{-3} \mathrm{mmol}\right), 4$-bromoanisole $(0.5 \mathrm{mmol})$, styrene $(1.0 \mathrm{mmol}), \mathrm{Cs}_{2} \mathrm{CO}_{3}(1.0 \mathrm{mmol}), \mathrm{DMF}(1.5 \mathrm{~mL}), \mathrm{decane}(0.05 \mathrm{~mL}), 1 \mathrm{~h}$. ${ }^{\mathrm{b}}$ Conversions were determined by GC using decane as internal standard.

for $1 \mathrm{~h}$ with styrene in $\mathrm{N}, \mathrm{N}$-dimethylformamide (DMF) in the presence of $\mathrm{Cs}_{2} \mathrm{CO}_{3}$ (Table 3). The runs were carried out at different temperatures and L:M ratios. The highest yield (46.5\%) was obtained when operating with 1 mol-\% catalyst and one equivalent of HUGPHOS-2 per palladium (Table 3, entry 5). Higher phosphine:Pd ratios did not improve the catalytic outcome (Table 3, entry 4). These results clearly indicate that a single phosphine ligand is sufficient to stabilise the active palladium species. We observed that by raising the temperature to $130{ }^{\circ} \mathrm{C}$, the conversions remained practically unchanged (Table 3 , entry 6 ). For comparison purposes, we also assessed the catalytic behaviour of the related diphosphine WIDEPHOS [39,52]. When using a WIDEPHOS:Pd ratio of $1: 1$, practically no reaction occurred (Table 3 , entry 5 ). This is probably caused by the formation of a stable pseudo-transchelate complex with this ligand, which forbids completion of the catalytic cycle $[66,67]$. Clearly, decoordination of a phosphine end cannot take place in this stable trans complex, which seems vital for completion of the whole catalytic cycle [68]. However, when applying a WIDEPHOS:Pd ratio of 1:2, the reaction proceeded with $10.4 \%$ conversion (Table 3 , entry 2 ). With the same ratio and by raising the temperature to $130{ }^{\circ} \mathrm{C}$, the conversion increased to $20.7 \%$ (Table 3 , entry 3 ). These results suggest that in the presence of an excess palladium, WIDEPHOS operates as a ligand with two independent monophosphine arms, each of them binding a palladium atom.

We then applied the aforementioned optimal conditions in the coupling of styrene with different aryl bromides (Table 4), using either HUGPHOS-(1 or 2) or WIDEPHOS as ligands. In the case of HUGPHOS-2, a conversion of $61.0 \%$ was observed for 4-bromotoluene, while the 3- and 2-substituted isomers led to conversions of $37.9 \%$ and $28.6 \%$, respectively (Table 4 , entries 2-4). Not surprisingly, the activated 2-bromo-6methoxynaphtalene afforded the corresponding coupling product in relatively high yield ( $71 \%$; Table 4 , entry 5). As already observed in the hydroformylation experiments, HUGPHOS-1 generally gave slightly better results than the larger HUGPHOS-2, which points to a catalytic reaction taking place outside the cavity. It is noteworthy that the activities obtained in Mizoroki-Heck coupling with the above catalytic systems lie in the range obtained with other phosphines $[69,70]$, these being, however, always used in excess [2,71]. In fact, HUGPHOSderived catalysts are much more active than previously reported CD-based Heck coupling catalysts [72]. The relatively low performance of WIDEPHOS, when operating as a bis(monodentate) ligand, is probably the result of the severe steric encumbrance generated within the cavity of the postulated dinuclear complex.

According to a number of mechanistic studies, the structure of the catalytic intermediates of Mizoroki-Heck reactions is strongly dependent on the phosphine used [73-81]. With very bulky monophosphines, active species having only one phosphine coordinated to the metal have been proposed $[80,82]$. In view of the above complexation studies, such mono-ligated intermediates are also likely to be operative with HUGPHOS ligands (Scheme 9). The fact that the observed reaction rates are higher with HUGPHOS ligands than with other bulky phosphines may be related to the presence of hemilabile methoxy groups [83] able either to stabilise highly reactive intermediates or assist the reduction-elimination step [80,82]. 
Table 4: Palladium-catalysed Mizoroki-Heck cross-coupling of arylbromides with styrene using HUGPHOS-1, HUGPHOS-2 and WIDEPHOS. ${ }^{a}$

entry $\quad \mathrm{ArBr} \quad$ conv [\% $]^{\mathrm{b}}$

HUGPHOS-1 HUGPHOS-2

WIDEPHOS

1<smiles>COc1ccc(Br)cc1</smiles><smiles>Cc1ccc(Br)cc1</smiles>

3

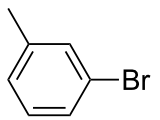

4

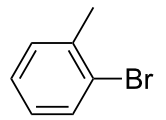

5<smiles>COc1ccc2cc(Br)ccc2c1</smiles>

58.3

50.5

42.4

37.9

32.5

80.6

71.1

74.2

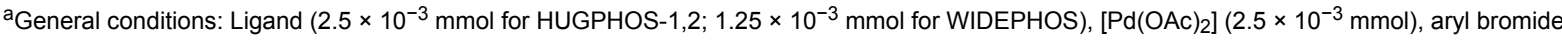
$(0.25 \mathrm{mmol})$, styrene $(0.50 \mathrm{mmol}), \mathrm{Cs}_{2} \mathrm{CO}_{3}(0.50 \mathrm{mmol})$, DMF $(0.750 \mathrm{~mL})$, decane $(0.025 \mathrm{~mL}), T=130^{\circ} \mathrm{C}, 1 \mathrm{~h}$.

${ }^{\mathrm{b}}$ Conversions were determined by GC using decane as internal standard.

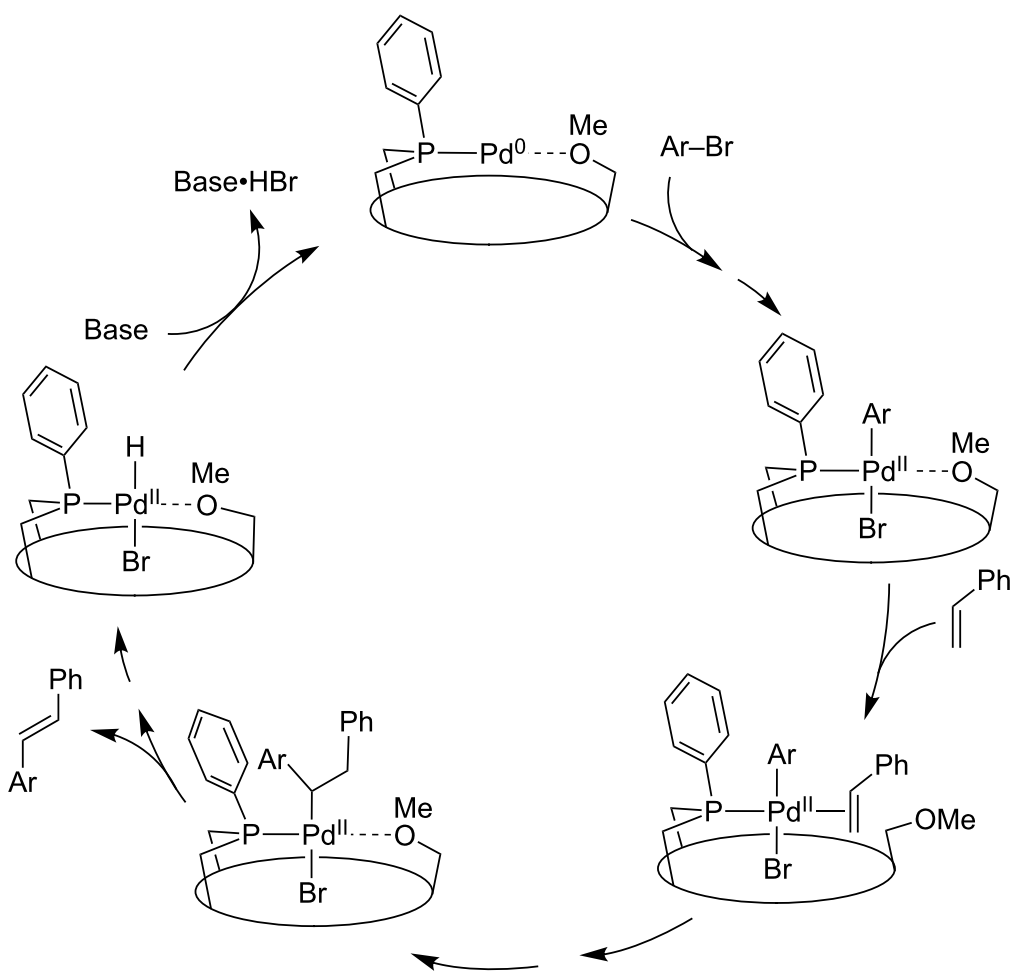




\section{Conclusion}

In conclusion, we have shown that the cavity-shaped phosphines HUGPHOS-1 and HUGPHOS-2 exclusively form monophosphine complexes with $\mathrm{Pd}(\mathrm{II}), \mathrm{Pt}(\mathrm{II}), \mathrm{Rh}(\mathrm{I})$, and $\mathrm{Ru}(\mathrm{II})$ cations. In all these complexes, the CD cavity tightly embraces the metal centre. Such a feature has a strong influence on the catalytic outcome of both olefin hydroformylation and Heck coupling reactions. Despite being generally regarded as incompatible, both high regio- and high enantioselectivity were observed with HUGPHOS ligands in the Rh-catalysed hydroformylation of styrene. In these systems, the high isoselectivity arises from the ligand ability to exclusively generate monophosphine complexes while the high enantioselectivity is a result of the efficient chirality transfer imposed by the embracing character of the chiral CD cavity. To the best of our knowledge, the chiral inductions obtained with these ligands are the highest ever observed for a CD-derived catalyst operating in organic media [46,84-88]. Future work is aimed at extending the applications of HUGPHOS ligands to other metal-catalysed reactions.

\section{Experimental}

All commercial reagents were used as supplied. All manipulations were performed in Schlenk-type flasks under $\mathrm{N}_{2}$. Solvents were dried by conventional methods and distilled immediately prior to use. Column chromatography was performed on silica gel 60 (particle size $40-63 \mu \mathrm{m}, 230-240$ mesh). $\mathrm{CDCl}_{3}$ was passed down a $5 \mathrm{~cm}$ thick alumina column and stored under $\mathrm{N}_{2}$ over molecular sieves $(3 \AA)$. Routine ${ }^{1} \mathrm{H},{ }^{13} \mathrm{C}\left\{{ }^{1} \mathrm{H}\right\}$ and ${ }^{31} \mathrm{P}\left\{{ }^{1} \mathrm{H}\right\}$ NMR spectra were recorded with Bruker FT instruments (AVANCE 300, 400, 500, 600 spectrometers). ${ }^{1} \mathrm{H}$ NMR spectral data were referenced to residual protiated solvents $\left(\delta=7.26 \mathrm{ppm}\right.$ for $\left.\mathrm{CDCl}_{3}\right),{ }^{13} \mathrm{C}$ chemical shifts are reported relative to deuterated solvents $\left(\delta=77.16 \mathrm{ppm}\right.$ for $\left.\mathrm{CDCl}_{3}\right)$ and the ${ }^{31} \mathrm{P}$ NMR data are given relative to external $\mathrm{H}_{3} \mathrm{PO}_{4}$. Mass spectra were recorded either on a Maldi TOF spectrometer (MALDI-TOF) using $\alpha$-cyano-4-hydroxycinnamic acid as matrix, or on a Bruker MicroTOF spectrometer (ESI-TOF) using $\mathrm{CH}_{2} \mathrm{Cl}_{2}, \mathrm{MeCN}$ or $\mathrm{MeOH}$ as the solvent. Elemental analyses were performed by the Service de Microanalyse, Institut de Chimie UMR 7177, Strasbourg. Melting points were determined with a Büchi 535 capillary melting point apparatus. The catalytic solutions containing the aldehydes were analysed by using a Varian 3900 gas chromatograph equipped with a WCOT fused-silica column $(25 \mathrm{~m} \times 0.25 \mathrm{~mm})$. This allowed to determine the b:1 ratio. In order to determine the enantiomeric excess, a sample of the reaction mixture (toluene) was treated with $\mathrm{LiAlH}_{4}$ for $0.5 \mathrm{~h}$. After filtration, the toluene solution containing enantiomeric alcohols was analysed by $\mathrm{GC}$ with a Chirasil-DEX CB column $(25 \mathrm{~m} \times 0.25 \mathrm{~mm})$. HUGPHOS- 1 , HUGPHOS-2 [38], WIDEPHOS [39], and [PdCl(dmba) $]_{2}$ [89], were synthesized according to literature procedures. The synthesis and characterisation of compounds 5, 9, 12 and 13, as well as the general procedure for rhodium catalysed hydroformylation reactions have been reported in a preliminary communication [44]. In the present full paper, the glucose units are ranged clockwise when looking at the primary face. The numbering of the atoms within a glucose unit is as follows:

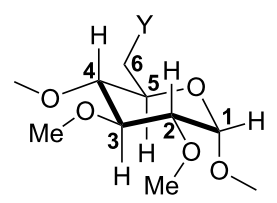

2: A solution of $\left[(\mathrm{PdCl}(\mathrm{dmba})]_{2}(0.170 \mathrm{~g}, 0.30 \mathrm{mmol})\right.$ in $\mathrm{CH}_{2} \mathrm{Cl}_{2}(20 \mathrm{~mL})$ was added to a solution of HUGPHOS-2 ( $0.900 \mathrm{~g}, 0.61 \mathrm{mmol})$ in $\mathrm{CH}_{2} \mathrm{Cl}_{2}(10 \mathrm{~mL})$ under vigorous stirring at room temperature. After $15 \mathrm{~min}$, the solvent was removed in vacuo and the residue was subjected to column chromatography $\left(\mathrm{CH}_{2} \mathrm{Cl}_{2} / \mathrm{MeOH}, 97: 3, \mathrm{v} / \mathrm{v}\right)$ to afford pure 2 $(0.900 \mathrm{~g}, 84 \%)$ as a pale yellow solid. $R_{\mathrm{f}}\left(\mathrm{SiO}_{2}, \mathrm{CH}_{2} \mathrm{Cl}_{2} / \mathrm{MeOH}\right.$, $94: 6, \mathrm{v} / \mathrm{v})=0.35 ; \mathrm{mp} \mathrm{dec} .>250{ }^{\circ} \mathrm{C} ;{ }^{1} \mathrm{H} \mathrm{NMR}(300.1 \mathrm{MHz}$, $\left.\mathrm{CDCl}_{3}, 25^{\circ} \mathrm{C}\right) \delta$ (assignment by COSY, ROESY and HMQC) 1.73-1.86 (m, $\left.1 \mathrm{H}, \mathrm{H}-6 \mathrm{a}^{\mathrm{A}}\right), 2.51-2.59\left(\mathrm{~m}, 1 \mathrm{H}, \mathrm{H}-6 \mathrm{a}^{\mathrm{B}}\right), 2.66(\mathrm{~s}$, $3 \mathrm{H}, \mathrm{NMe}), 2.88$ (s, 3H, NMe), 3.03-3.31 (10H, H-2, H-4 ${ }^{\mathrm{A}, \mathrm{B}}$, H-6), 3.12 (s, 3H, OMe), 3.36 (s, 3H, OMe), 3.41 (s, 3H, OMe), 3.43 (s, 6H, OMe), 3.44 (s, 3H, OMe), 3.45 (s, 3H, OMe), 3.47 (s, 3H, OMe), $3.48(\mathrm{~s}, 6 \mathrm{H}, \mathrm{OMe}), 3.51(\mathrm{~s}, 6 \mathrm{H}, \mathrm{OMe}), 3.60(\mathrm{~s}$, $3 \mathrm{H}, \mathrm{OMe}), 3.62$ (s, 6H, OMe), 3.63 (s, 3H, OMe), 3.66 (s, 3H, $\mathrm{OMe}), 3.70$, (s, 3H, OMe), 3.71 (s, 3H, OMe), 3.40-3.91 (29H, H-3, H-4, H-5, H-6, H-6b $\left.{ }^{\mathrm{A}, \mathrm{B}}, \mathrm{NCH}_{2}\right), 3.98$ (d, 1H, ${ }^{2} J_{\mathrm{H}-6 \mathrm{~b}, \mathrm{H}-6 \mathrm{a}}=$ $10.1 \mathrm{~Hz}, \mathrm{H}-6), 4.17\left(\mathrm{~d}, 1 \mathrm{H},{ }^{2} J=12.9 \mathrm{~Hz}, \mathrm{NCH}_{2}\right), 4.49$ (d, $1 \mathrm{H}$, $\left.{ }^{3} J_{\mathrm{H}-5, \mathrm{H}-6}=9.3 \mathrm{~Hz}, \mathrm{H}-5\right), 4.86\left(\mathrm{~d}, 1 \mathrm{H},{ }^{3} J_{\mathrm{H}-1, \mathrm{H}-2}=1.7 \mathrm{~Hz}, \mathrm{H}-1\right)$, $4.87\left(\mathrm{~m}, 1 \mathrm{H}, \mathrm{H}-5^{\mathrm{B}}\right), 4.88\left(\mathrm{~d}, 1 \mathrm{H},{ }^{3} J_{\mathrm{H}-1, \mathrm{H}-2}=3.9 \mathrm{~Hz}, \mathrm{H}-1\right), 5.00$ $\left(\mathrm{d}, 1 \mathrm{H},{ }^{3} J_{\mathrm{H}-1, \mathrm{H}-2}=3.3 \mathrm{~Hz}, \mathrm{H}-1\right), 5.03\left(\mathrm{~d}, 1 \mathrm{H},{ }^{3} J_{\mathrm{H}-1, \mathrm{H}-2}=4.6 \mathrm{~Hz}\right.$, $\mathrm{H}-1), 5.04\left(\mathrm{~m}, 1 \mathrm{H}, \mathrm{H}-5^{\mathrm{A}}\right), 5.07$ (d, $\left.1 \mathrm{H},{ }^{3} J_{\mathrm{H}-1, \mathrm{H}-2}=3.1 \mathrm{~Hz}, \mathrm{H}-1\right)$, $5.09\left(\mathrm{~d}, 1 \mathrm{H},{ }^{3} J_{\mathrm{H}-1, \mathrm{H}-2}=4.0 \mathrm{~Hz}, \mathrm{H}-1\right), 5.10\left(\mathrm{~d}, 1 \mathrm{H},{ }^{3} J_{\mathrm{H}-1, \mathrm{H}-2}=\right.$ $3.8 \mathrm{~Hz}, \mathrm{H}-1), 6.31$ (t, $1 \mathrm{H}, J=6.9 \mathrm{~Hz}, o-\mathrm{H}$ of dmba), $6.46(\mathrm{t}, 1 \mathrm{H}$, $J=7.5 \mathrm{~Hz}, m-\mathrm{H}$ of dmba), $6.78(\mathrm{t}, 1 \mathrm{H}, J=7.3 \mathrm{~Hz}, p-\mathrm{H}$ of dmba), 6.93 (d, 1H, $J=7.5 \mathrm{~Hz}, m-\mathrm{H}$ of dmba), 7.23-7.31 (m, $3 \mathrm{H}, m-\mathrm{H}, p-\mathrm{H}), 7.65-7.71(\mathrm{~m}, 2 \mathrm{H}, o-\mathrm{H}) \mathrm{ppm} ;{ }^{13} \mathrm{C}\left\{{ }^{1} \mathrm{H}\right\} \mathrm{NMR}$ (75.5 MHz, $\mathrm{CDCl}_{3}, 25^{\circ} \mathrm{C}$ ) $\delta$ (assignment by HMQC) $32.94(\mathrm{~d}$, $\left.{ }^{1} J_{\mathrm{C}, \mathrm{P}}=23.5 \mathrm{~Hz}, \mathrm{C}-6^{\mathrm{A}}\right), 33.6\left(\mathrm{~d},{ }^{1} J_{\mathrm{C}, \mathrm{P}}=29.4 \mathrm{~Hz}, \mathrm{C}-6^{\mathrm{B}}\right), 49.63$ (br s, $\mathrm{NCH}_{3}$ ), 50.44 (br s, $\mathrm{NCH}_{3}$ ), 57.81, 57.96, 58.04, 58.19 [×2], 58.65, 58.75, $58.85[\times 2], 58.90[\times 2], 59.09,61.21,61.30$, $61.56,61.62,61.70[\times 2], 62.05(\mathrm{OMe}), 66.25\left(\mathrm{~d},{ }^{2} J_{\mathrm{C}, \mathrm{P}}=5.8\right.$ $\left.\mathrm{Hz}, \mathrm{C}-5^{\mathrm{A}}\right), 70.17\left(\mathrm{~d},{ }^{2} J_{\mathrm{C}, \mathrm{P}}=7.8 \mathrm{~Hz}, \mathrm{C}-5^{\mathrm{B}}\right), 70.90[\times 2], 71.09$ [×2], $71.75(\mathrm{C}-5), 71.09,71.32,71.52,71.64,72.36(\mathrm{C}-6)$, $73.01\left(\mathrm{NCH}_{2}\right), 79.91,79.98,80.58,80.89$ [×2], 80.98, 81.19, $81.74[\times 3], 82.17,82.36,82.53,82.68[\times 2], 82.82,82.94,83.08$, 
83.45 (C-2, C-3, C-4), $88.02\left(\mathrm{~d},{ }^{3} J_{\mathrm{C}, \mathrm{P}}=9.5 \mathrm{~Hz}, \mathrm{C}-4^{\mathrm{A}}\right), 88.65(\mathrm{~d}$, $\left.{ }^{3} J_{\mathrm{C}, \mathrm{P}}=4.4 \mathrm{~Hz}, \mathrm{C}-4^{\mathrm{B}}\right), 96.57,97.94,98.79,100.20[\times 2], 100.29$, $101.58(\mathrm{C}-1), 122.01\left(\mathrm{~d},{ }^{4} J_{\mathrm{C}, \mathrm{P}}=2.3 \mathrm{~Hz}, \mathrm{dmba}-\mathrm{C}_{\text {meta }}\right), 123.52$ $\left(\mathrm{dmba}-\mathrm{C}_{\text {para }}\right), 125.36\left(\mathrm{~d},{ }^{4} J_{\mathrm{C}, \mathrm{P}}=6.0 \mathrm{~Hz}, \mathrm{dmba}-\mathrm{C}_{\text {meta }}\right), 128.15$ $\left(\mathrm{d},{ }^{3} J_{\mathrm{C}, \mathrm{P}}=10.4 \mathrm{~Hz}\right.$, dmba-C $\left.\mathrm{C}_{\text {ortho-H}}\right), 130.15\left(\mathrm{C}_{\text {para }}\right), 132.38(\mathrm{~d}$, $\left.{ }^{2} J_{\mathrm{C}, \mathrm{P}}=10.8 \mathrm{~Hz}, \mathrm{C}_{\text {ortho }}\right), 134.91\left(\mathrm{~d},{ }^{1} J_{\mathrm{C}, \mathrm{P}}=49.0 \mathrm{~Hz}, \mathrm{C}_{\text {ipso }}\right)$, $136.47\left(\mathrm{~d},{ }^{3} J_{\mathrm{C}, \mathrm{P}}=10.0 \mathrm{~Hz}, \mathrm{C}_{\text {meta }}\right), 147.67$ (dmba-C ortho-C $_{\text {C }}$, 152.44 (dmba-C ipso $_{\text {) ppm; }}{ }^{31} \mathrm{P}\left\{{ }^{1} \mathrm{H}\right\}$ NMR (121.5 $\mathrm{MHz} \mathrm{CDCl}_{3}$, $\left.25{ }^{\circ} \mathrm{C}\right) \delta 25.5$ (s) ppm; elemental analysis (\%) calcd for $\mathrm{C}_{76} \mathrm{H}_{123} \mathrm{ClNO}_{33} \mathrm{PPd}(1751.62)$ : C, 52.11; H, 7.08; N, 0.80; found: C, 52.34; H, 7.07; N, 0.80; MS (ESI-TOF): $m / z(\%)$ : $1714.67(100)[\mathrm{M}-\mathrm{Cl}]^{+}, 1774.64(4)[\mathrm{M}+\mathrm{Na}]^{+}, 1790.60(8)$ $[\mathrm{M}+\mathrm{K}]^{+}$.

6: Water was removed over $12 \mathrm{~h}$ by azeotropic distillation of a toluene solution $(100 \mathrm{~mL})$ of compound $\mathbf{5}(0.100 \mathrm{~g}, 0.06 \mathrm{mmol})$ using a Dean-Stark apparatus. After allowing the solution to reach room temperature, the solvent was removed in vacuo affording quantitatively compound $6(0.098 \mathrm{~g}, 0.06 \mathrm{mmol})$ as a colourless solid. mp dec. $>250{ }^{\circ} \mathrm{C}$; ${ }^{1} \mathrm{H}$ NMR $(300.1 \mathrm{MHz}$, $\left.\mathrm{CDCl}_{3}, 25^{\circ} \mathrm{C}\right) \delta$ (assignment by COSY and HMQC) 2.37 (m, $\left.1 \mathrm{H}, \mathrm{H}-6 \mathrm{a}^{\mathrm{A}}\right), 2.59\left(\mathrm{~m}, 1 \mathrm{H}, \mathrm{H}-6 \mathrm{a}^{\mathrm{B}}\right), 2.69\left(\mathrm{dd}, 1 \mathrm{H},{ }^{3} J_{\mathrm{H}-2, \mathrm{H}-3}=9.9\right.$ $\left.\mathrm{Hz},{ }^{3} J_{\mathrm{H}-2, \mathrm{H}-1}=2.8 \mathrm{~Hz}, \mathrm{H}-2\right), 2.93-3.07\left(2 \mathrm{H}, \mathrm{H}-6 \mathrm{~b}^{\mathrm{A}, \mathrm{B}}\right)$, 3.12-3.26 (5H, H-2), 3.34 (m, 3H, OMe), 3.38 (s, 3H, OMe), 3.39 (s, 3H, OMe), 3.40 (s, 3H, OMe), 3.43 (s, 3H, OMe), 3.48 (s, 6H, OMe), 3.51 (s, 12H, OMe), 3.56 (m, 3H, OMe), 3.60 (s, $3 \mathrm{H}, \mathrm{OMe}), 3.61$ (s, 3H, OMe), 3.63 (s, 6H, OMe), 3.64 (s, 3H, $\mathrm{OMe}), 3.65$ (s, 3H, OMe), 3.68 (m, 3H, OMe), 3.30-3.93 (27H, H-2, H-3, H-4, H-5, H-6), 3.99 (dd, $1 \mathrm{H},{ }^{2} J_{\mathrm{H}-6 \mathrm{~b}, \mathrm{H}-6 \mathrm{a}}=9.7 \mathrm{~Hz}$, $\left.{ }^{3} J_{\mathrm{H}-6 \mathrm{~b}, \mathrm{H}-5}=2.7 \mathrm{~Hz}, \mathrm{H}-6\right), 4.19\left(\mathrm{dd}, 1 \mathrm{H},{ }^{2} J_{\mathrm{H}-6 \mathrm{~b}, \mathrm{H}-6 \mathrm{a}}=11.0 \mathrm{~Hz}\right.$, $\left.{ }^{3} J_{\mathrm{H}-6 \mathrm{~b}, \mathrm{H}-5}=2.4 \mathrm{~Hz}, \mathrm{H}-6\right), 4.25(\mathrm{~m}, 1 \mathrm{H}, \mathrm{H}-5), 4.42(\mathrm{~m}, 1 \mathrm{H}$, $\left.\mathrm{H}-5^{\mathrm{A}}\right), 4.50\left(\mathrm{~m}, 1 \mathrm{H}, \mathrm{H}-5^{\mathrm{B}}\right), 4.85\left(\mathrm{~d}, 1 \mathrm{H},{ }^{3} J_{\mathrm{H}-1, \mathrm{H}-2}=4.7 \mathrm{~Hz}\right.$, $\mathrm{H}-1), 4.98\left(\mathrm{~d}, 1 \mathrm{H},{ }^{3} J_{\mathrm{H}-1, \mathrm{H}-2}=2.6 \mathrm{~Hz}, \mathrm{H}-1\right), 5.06(\mathrm{~d}, 1 \mathrm{H}$, $\left.{ }^{3} J_{\mathrm{H}-1, \mathrm{H}-2}=3.7 \mathrm{~Hz}, \mathrm{H}-1\right), 5.08\left(\mathrm{~d}, 1 \mathrm{H},{ }^{3} J_{\mathrm{H}-1, \mathrm{H}-2}=3.6 \mathrm{~Hz}, \mathrm{H}-1\right)$, $5.11\left(\mathrm{~d}, 1 \mathrm{H},{ }^{3} J_{\mathrm{H}-1, \mathrm{H}-2}=3.1 \mathrm{~Hz}, \mathrm{H}-1\right), 5.15\left(\mathrm{~d}, 1 \mathrm{H},{ }^{3} J_{\mathrm{H}-1, \mathrm{H}-2}=\right.$ $3.1 \mathrm{~Hz}, \mathrm{H}-1), 5.21\left(\mathrm{~d}, 1 \mathrm{H},{ }^{3} J_{\mathrm{H}-1, \mathrm{H}-2}=3.1 \mathrm{~Hz}, \mathrm{H}-1\right), 7.33-7.45$ $(3 \mathrm{H}, m-\mathrm{H}, p-\mathrm{H}), 7.97\left(\mathrm{ddd}, 2 \mathrm{H},{ }^{3} J_{o-\mathrm{H}, \mathrm{P}}=12.1 \mathrm{~Hz},{ }^{3} J_{o-\mathrm{H}, m-\mathrm{H}}=\right.$ $\left.6.9 \mathrm{~Hz},{ }^{3} J_{o-\mathrm{H}, p-\mathrm{H}}=1.0 \mathrm{~Hz}, o-\mathrm{H}\right) \mathrm{ppm} ;{ }^{13} \mathrm{C}\left\{{ }^{1} \mathrm{H}\right\} \mathrm{NMR}(75.5$ $\left.\mathrm{MHz}, \mathrm{CDCl}_{3}, 25^{\circ} \mathrm{C}\right) \delta$ (assignment by HMQC) 27.94-28.09 $\left(\mathrm{m}, \mathrm{C}-6^{\mathrm{A}, \mathrm{B}}\right), 57.89,58.29[\times 2], 58.59[\times 2], 58.62[\times 2], 59.01$, $59.05,59.11,59.25[\times 2], 60.77,60.98,61.04,61.32,61.36$, 61.65, $61.71(\mathrm{OMe}), 65.36\left(\mathrm{~d},{ }^{2} J_{\mathrm{C}, \mathrm{P}}=8.6 \mathrm{~Hz}, \mathrm{C}-5^{\mathrm{B}}\right), 69.30(\mathrm{~d}$, $\left.{ }^{2} J_{\mathrm{C}, \mathrm{P}}=3.9 \mathrm{~Hz}, \mathrm{C}-5^{\mathrm{A}}\right), 70.80,71.09[\times 2], 71.26,71.52(\mathrm{C}-5)$, $71.10,71.36[\times 2], 71.43,71.61(\mathrm{C}-6), 79.15,79.39,79.91$, $80.03,80.12,80.82,80.87,81.19,81.32,81.42,81.49,81.84$ [×2], $81.89[\times 2], 82.10,82.24,82.35,82.41,83.53,84.17(\mathrm{C}-2$, C-3, C-4), 96.98, 97.26, 98.79, 98.97, 99.36, 99.47, 99.64 (C-1), $128.57\left(\mathrm{C}_{\text {para }}\right), 128.97\left(\mathrm{~d},{ }^{3} J_{\mathrm{C}, \mathrm{P}}=5.8 \mathrm{~Hz}, \mathrm{C}_{\text {meta }}\right), 131.46(\mathrm{~d}$, $\left.{ }^{1} J_{\mathrm{C}, \mathrm{P}}=50.6 \mathrm{~Hz}, \mathrm{C}_{\text {ipso }}\right), 132.53\left(\mathrm{~d},{ }^{2} J_{\mathrm{C}, \mathrm{P}}=10.5 \mathrm{~Hz}, \mathrm{C}_{\text {ortho }}\right) \mathrm{ppm}$; ${ }^{31} \mathrm{P}\left\{{ }^{1} \mathrm{H}\right\}$ NMR $\left(121.5 \mathrm{MHz} \mathrm{CDCl}_{3}, 25{ }^{\circ} \mathrm{C}\right) \delta 19.8$ (s) ppm; MS (ESI-TOF): $m / z(\%): 1673.52(40)[\mathrm{M}+\mathrm{Na}]^{+}$. We do not provide microanalytical data for this compound because of fast rehydration in air.

7 and 8: A solution of HUGPHOS-2 (0.126 g, $0.09 \mathrm{mmol})$ in $\mathrm{CH}_{2} \mathrm{Cl}_{2}(5 \mathrm{~mL})$ was added dropwise to a solution of $\left[\mathrm{RuCl}_{2}\left(\eta^{6}-\right.\right.$ p-cymene $)]_{2}(0.052 \mathrm{~g}, 0.08 \mathrm{mmol})$ in $\mathrm{CH}_{2} \mathrm{Cl}_{2}(5 \mathrm{~mL})$ under vigorous stirring at room temperature. The solution was stirred for $1 \mathrm{~h}$ before being evaporated to dryness. The crude product was purified by column chromatography $\left(\mathrm{SiO}_{2}, \mathrm{CH}_{2} \mathrm{Cl}_{2} / \mathrm{MeOH}\right.$, $97: 3$ to $95: 5, v / v)$ affording $7(0.085 \mathrm{~g}, 56 \%)$ and $8(0.065 \mathrm{~g}$, $42 \%)$ as brown solids. 7: $\mathrm{mp} 210{ }^{\circ} \mathrm{C} ;{ }^{1} \mathrm{H}$ NMR (500.1 MHz, $\left.\mathrm{CDCl}_{3}, 25^{\circ} \mathrm{C}\right) \delta$ (assignment by combined COSY, ROESY and HSQC) $1.13\left(\mathrm{~d}, 3 \mathrm{H},{ }^{3} J_{\mathrm{CH} 3, \mathrm{CH}}=7.1 \mathrm{~Hz}, \mathrm{CH}_{3}{ }^{\mathrm{iPr}}\right.$ of $p$-cymene), $1.15\left(\mathrm{~d}, 3 \mathrm{H},{ }^{3} J_{\mathrm{CH} 3, \mathrm{CH}}=7.1 \mathrm{~Hz}, \mathrm{CH}_{3}{ }^{\text {iPr' }}\right.$ of $p$-cymene), $1.63(\mathrm{~s}$, $3 \mathrm{H}, \mathrm{CH}_{3}$ of $p$-cymene), $2.57\left(\mathrm{ddd}, 1 \mathrm{H},{ }^{2} J_{\mathrm{H}-6 \mathrm{a}, \mathrm{H}-6 \mathrm{~b}}=15.3 \mathrm{~Hz}\right.$, $\left.{ }^{2} J_{\mathrm{H}-6 \mathrm{a}, \mathrm{P}}=11.4 \mathrm{~Hz},{ }^{3} J_{\mathrm{H}-6 \mathrm{a}, \mathrm{H}-5}=2.5 \mathrm{~Hz}, \mathrm{H}-6 \mathrm{a}^{\mathrm{A}}\right), 2.71$ (sept, $1 \mathrm{H}$, ${ }^{3} J_{\mathrm{CH}, \mathrm{CH} 3}=7.1 \mathrm{~Hz}, \mathrm{CH}^{\mathrm{iPr}}$ of $p$-cymene $), 3.00\left(\mathrm{dd}, 1 \mathrm{H},{ }^{3} J_{\mathrm{H}-2, \mathrm{H}-1}\right.$ $\left.=2.9 \mathrm{~Hz},{ }^{3} J_{\mathrm{H}-2, \mathrm{H}-3}=9.8 \mathrm{~Hz}, \mathrm{H}-2\right), 3.19(\mathrm{~s}, 3 \mathrm{H}, \mathrm{OMe}), 3.34(\mathrm{~s}$, $3 \mathrm{H}, \mathrm{OMe}$ ), 3.35 (s, $3 \mathrm{H}, \mathrm{OMe}), 3.40$ (s, 3H, OMe), 3.41 (s, $3 \mathrm{H}$, $\mathrm{OMe}), 3.45$ (s, 3H, OMe), 3.46 (s, 3H, OMe), 3.47 (s, 3H, $\mathrm{OMe}), 3.48$ (s, 3H, OMe), 3.51 (s, 3H, OMe), 3.52 (s, 3H, $\mathrm{OMe}), 3.53$ (s, 3H, OMe), 3.54 (s, 3H, OMe), 3.56 (s, 3H, $\mathrm{OMe}), 3.58$ (s, 3H, OMe), 3.62 (s, 3H, OMe), 3.63 (s, 3H, $\mathrm{OMe}$ ), 3.69 (s, 3H, OMe), 3.82 (s, 3H, OMe), 3.06-3.85 (36H, H-2, H-3, H-4, H-5, H-6), 3.88 (dd, $1 \mathrm{H},{ }^{2} J_{\mathrm{H}-6 \mathrm{a}, \mathrm{H}-6 \mathrm{~b}}=10.8 \mathrm{~Hz}$, $\left.{ }^{3} J_{\mathrm{H}-6 \mathrm{a}, \mathrm{H}-5}=4.3 \mathrm{~Hz}, \mathrm{H}-6\right), 3.91-3.95$ (m, 1H, H-5), 4.02-4.10 (2 $\left.\mathrm{H}, \mathrm{H}-5, \mathrm{H}-5^{\mathrm{A}}\right), 4.82\left(\mathrm{~d}, 1 \mathrm{H},{ }^{3} J_{\mathrm{H}-1, \mathrm{H}-2}=2.8 \mathrm{~Hz}, \mathrm{H}-1\right), 4.88$ (dd, $1 \mathrm{H},{ }^{3} J_{m-\mathrm{H}, o-\mathrm{H}}=5.6 \mathrm{~Hz},{ }^{3} J_{m-\mathrm{H}, m-\mathrm{H}}=2.3 \mathrm{~Hz}, m-\mathrm{H}$ of $p$-cymene), $4.95\left(\mathrm{~d}, 1 \mathrm{H},{ }^{3} J_{\mathrm{H}-1, \mathrm{H}-2}=4.1 \mathrm{~Hz}, \mathrm{H}-1\right), 5.04\left(\mathrm{~d}, 1 \mathrm{H},{ }^{3} J_{\mathrm{H}-1, \mathrm{H}-2}=\right.$ $3.9 \mathrm{~Hz}, \mathrm{H}-1), 5.05\left(\mathrm{~d}, 1 \mathrm{H},{ }^{3} J_{\mathrm{H}-1, \mathrm{H}-2}=3.5 \mathrm{~Hz}, \mathrm{H}-1\right), 5.06-5.09$ $\left(2 \mathrm{H}, \mathrm{H}-1, o-\mathrm{H}\right.$ of $p$-cymene), 5.14-5.18 $\left(2 \mathrm{H}, \mathrm{H}-1, o-\mathrm{H}^{\prime}\right.$ of $p$-cymene), 5.26-5.29 (m, $1 \mathrm{H}, m-\mathrm{H}^{\prime}$ of $p$-cymene), $5.36(\mathrm{~d}, 1 \mathrm{H}$, $\left.{ }^{3} J_{\mathrm{H}-1, \mathrm{H}-2}=4.1 \mathrm{~Hz}, \mathrm{H}-1\right), 7.45-7.56(3 \mathrm{H}, m-\mathrm{H}, p-\mathrm{H}), 7.91-7.96$ (2 H,o-H) ppm; ${ }^{13} \mathrm{C}\left\{{ }^{1} \mathrm{H}\right\} \mathrm{NMR}\left(125.8 \mathrm{MHz}, \mathrm{CDCl}_{3}, 25{ }^{\circ} \mathrm{C}\right) \delta$ (assignment by HSQC) $=16.32\left(\mathrm{CH}_{3}\right.$ of $p$-cymene $), 21.04$, $21.10\left(\mathrm{CH}_{3}{ }^{\mathrm{iPr}}\right.$ of $p$-cymene $), 27.26\left(\mathrm{~d},{ }^{1} J_{\mathrm{C}, \mathrm{P}}=27.8 \mathrm{~Hz}, \mathrm{C}-6^{\mathrm{A}}\right)$, $27.36\left(\mathrm{~d},{ }^{1} J_{\mathrm{C}, \mathrm{P}}=23.8 \mathrm{~Hz}, \mathrm{C}-6^{\mathrm{B}}\right), 29.50$ ( $\mathrm{CH}$ of $p$-cymene), 55.99, 56.99, 57.61, 57.74, 57.77, 57.83, 58.05, 58.13, 58.16, $58.26,58.33,59.00,59.69,60.01,60.24,60.44,60.61,60.64$, $60.81,63.79\left(\mathrm{~d},{ }^{2} J_{\mathrm{C}, \mathrm{P}}=9.4 \mathrm{~Hz}, \mathrm{C}-5^{\mathrm{A}}\right), 68.48\left(\mathrm{~d},{ }^{2} J_{\mathrm{C}, \mathrm{P}}=10.1\right.$ $\left.\mathrm{Hz}, \mathrm{C}-5^{\mathrm{B}}\right), 69.88[\times 2](\mathrm{C}-6), 69.94[\times 2], 70.39(\mathrm{C}-5), 70.46$, 70.55 (C-6), 70.70 (C-5), 70.82 (C-6), 71.76 (C-5), 76.84, $78.21,79.16,79.80[\times 2], 79.93,80.09,80.34[\times 2], 80.45,80.61$, $80.68,81.01,81.20,81.32$ [×2], $81.61[\times 2], 81.93,82.74,84.46$, 87.88 (C-2, C-3, C-4, $\mathrm{C}_{\text {ortho }}$ of p-cymene), 88.64, 90.43 ( $\mathrm{C}_{\text {meta }}$ of $p$-cymene), 91.55 ( $\mathrm{C}_{\text {ipso }}$ of $p$-cymene), 95.27, 96.29, 96.73, 98.54, 98.74, $98.92[\times 2](\mathrm{C}-1), 109.23\left(\mathrm{C}_{\text {ipso }}\right.$ of $p$-cymene), 127.74, $127.81\left(\mathrm{C}_{\text {meta }}\right), 129.17\left(\mathrm{C}_{\text {para }}\right), 130.30,130.35\left(\mathrm{C}_{\text {ortho }}\right)$, $132.65\left(\mathrm{~d},{ }^{1} J_{\mathrm{C}, \mathrm{P}}=38.3 \mathrm{~Hz}, \mathrm{C}_{i p s o}\right) \mathrm{ppm} ;{ }^{31} \mathrm{P}\left\{{ }^{1} \mathrm{H}\right\} \mathrm{NMR}(161.9$ $\mathrm{MHz}, \mathrm{CDCl}_{3}, 25{ }^{\circ} \mathrm{C}$ ) $\delta 20.4$ (s) ppm; elemental analysis (\%) calcd for $\mathrm{C}_{77} \mathrm{H}_{125} \mathrm{Cl}_{2} \mathrm{O}_{33} \mathrm{PRu} \cdot \mathrm{CH}_{2} \mathrm{Cl}_{2}$ (1781.75 + 84.93): $\mathrm{C}$, 
50.19; H, 6.86; found: C, 50.05; H, 6.80; MS (ESI-TOF): $\mathrm{m} / \mathrm{z}$ (\%): $1803.62(100)[M+\mathrm{Na}]^{+} .8: \mathrm{mp} 210{ }^{\circ} \mathrm{C} ;{ }^{1} \mathrm{H}$ NMR (500.1 $\mathrm{MHz}, \mathrm{CDCl}_{3}, 25{ }^{\circ} \mathrm{C}$ ) $\delta$ (assignment by combined COSY, ROESY and HSQC) $0.94\left(\mathrm{~d}, 3 \mathrm{H},{ }^{3} J_{\mathrm{CH} 3, \mathrm{CH}}=7.1 \mathrm{~Hz}, \mathrm{CH}_{3}{ }^{\mathrm{iPr}}\right.$ of $p$-cymene), $1.05\left(\mathrm{~d}, 3 \mathrm{H},{ }^{3} J_{\mathrm{CH} 3, \mathrm{CH}}=7.1 \mathrm{~Hz}, \mathrm{CH}_{3}{ }^{\mathrm{iPr}}\right.$ ' of p-cymene), 1.73 (s, $3 \mathrm{H}, \mathrm{CH}_{3}$ of $p$-cymene), 2.28 (sept, $1 \mathrm{H}$, ${ }^{3} J_{\mathrm{CH}, \mathrm{CH} 3}=7.1 \mathrm{~Hz}, \mathrm{CH}^{\mathrm{iPr}}$ of $p$-cymene $), 2.50(\mathrm{dt}, 1 \mathrm{H}$, $\left.{ }^{2} J_{\mathrm{H}-6 \mathrm{a}, \mathrm{H}-6 \mathrm{~b}}=18.2 \mathrm{~Hz},{ }^{2} J_{\mathrm{H}-6 \mathrm{a}, \mathrm{P}}={ }^{3} J_{\mathrm{H}-6 \mathrm{a}, \mathrm{H}-5}=7.2 \mathrm{~Hz}, \mathrm{H}-6 \mathrm{a}^{\mathrm{A}}\right)$, $2.59\left(\mathrm{dd}, 1 \mathrm{H},{ }^{3} J_{\mathrm{H}-2, \mathrm{H}-1}=3.1 \mathrm{~Hz},{ }^{3} J_{\mathrm{H}-2, \mathrm{H}-3}=9.9 \mathrm{~Hz}, \mathrm{H}-2^{\mathrm{A}}\right)$, $2.75\left(\mathrm{ddd}, 1 \mathrm{H},{ }^{2} J_{\mathrm{H}-6 \mathrm{a}, \mathrm{H}-6 \mathrm{~b}}=14.3 \mathrm{~Hz},{ }^{2} J_{\mathrm{H}-6 \mathrm{a}, \mathrm{P}}=12.0 \mathrm{~Hz}\right.$, $\left.{ }^{3} J_{\mathrm{H}-6 \mathrm{a}, \mathrm{H}-5}=2.6 \mathrm{~Hz}, \mathrm{H}-6 \mathrm{a}^{\mathrm{B}}\right), 2.88\left(\mathrm{t}, 1 \mathrm{H},{ }^{3} J_{\mathrm{H}-4, \mathrm{H}-3}={ }^{3} J_{\mathrm{H}-4, \mathrm{H}-5}=\right.$ $9.5 \mathrm{~Hz}, \mathrm{H}-4^{\mathrm{A}}$ ), 3.12-3.27 (7H, H-2, H-6b ${ }^{\mathrm{B}}$ ), 3.35 (s, 3H, OMe), $3.36(\mathrm{~s}, 3 \mathrm{H}, \mathrm{OMe}), 3.38$ (s, 3H, OMe), 3.39 (s, 3H, OMe), 3.40 (s, 3H, OMe), 3.41 (s, 3H, OMe), 3.45 (s, 3H, OMe), 3.46 (s, $3 \mathrm{H}, \mathrm{OMe}$ ), 3.48 (s, 6H, OMe), 3.49 (s, 3H, OMe), 3.53 (s, 3H, $\mathrm{OMe}), 3.56$ (s, 3H, OMe), 3.57 (s, 3H, OMe), 3.58 (s, 3H, $\mathrm{OMe}), 3.61$ (s, 3H, OMe), $3.62(\mathrm{~s}, 3 \mathrm{H}, \mathrm{OMe}), 3.63(\mathrm{~s}, 3 \mathrm{H}$, OMe), 3.64 (s, 3H, OMe), 3.33-3.87 (26H, H-3, H-4, H-5, $\mathrm{H}-6), 3.92\left(\mathrm{dd}, 1 \mathrm{H},{ }^{2} J_{\mathrm{H}-6 \mathrm{a}, \mathrm{H}-6 \mathrm{~b}}=10.3 \mathrm{~Hz},{ }^{3} J_{\mathrm{H}-6 \mathrm{a}, \mathrm{H}-5}=2.5 \mathrm{~Hz}\right.$, $\mathrm{H}-6), 4.10\left(\mathrm{~d}, 1 \mathrm{H},{ }^{2} J_{\mathrm{H}-6 \mathrm{a}, \mathrm{H}-6 \mathrm{~b}}=10.3 \mathrm{~Hz}, \mathrm{H}-6\right), 4.21-4.32(2 \mathrm{H}$, $\left.\mathrm{H}-5^{\mathrm{B}}, \mathrm{H}-6\right), 4.35$ (ddd, $1 \mathrm{H},{ }^{2} J_{\mathrm{H}-5, \mathrm{H}-6 \mathrm{a}}=7.2 \mathrm{~Hz},{ }^{2} J_{\mathrm{H}-5, \mathrm{H}-6 \mathrm{~b}}=$ $\left.26.1 \mathrm{~Hz},{ }^{3} J_{\mathrm{H}-5, \mathrm{H}-4}=10.9 \mathrm{~Hz}, \mathrm{H}-5^{\mathrm{A}}\right), 4.73\left(\mathrm{~d}, 1 \mathrm{H},{ }^{3} J_{\mathrm{H}-1, \mathrm{H}-2}=\right.$ $5.1 \mathrm{~Hz}, \mathrm{H}-1), 4.74\left(\mathrm{~d}, 1 \mathrm{H},{ }^{3} J_{o-\mathrm{H}, m-\mathrm{H}}=5.9 \mathrm{~Hz}, o-\mathrm{H}^{\prime}\right.$ of $p$-cymene), $4.95\left(\mathrm{~d}, 1 \mathrm{H},{ }^{3} J_{m-\mathrm{H}, o-\mathrm{H}}=5.9 \mathrm{~Hz}, m-\mathrm{H}^{\prime}\right.$ of $p$-cymene), $4.96\left(\mathrm{~d}, 1 \mathrm{H},{ }^{3} J_{\mathrm{H}-1, \mathrm{H}-2}=2.4 \mathrm{~Hz}, \mathrm{H}-1\right), 4.98\left(\mathrm{~d}, 1 \mathrm{H},{ }^{3} J_{\mathrm{H}-1, \mathrm{H}-2}=\right.$ $2.7 \mathrm{~Hz}, \mathrm{H}-1), 5.06\left(\mathrm{~d}, 1 \mathrm{H},{ }^{3} J_{\mathrm{H}-1, \mathrm{H}-2}=3.1 \mathrm{~Hz}, \mathrm{H}-1\right), 5.10(\mathrm{~d}, 1 \mathrm{H}$, $\left.{ }^{3} J_{\mathrm{H}-1, \mathrm{H}-2}=3.2 \mathrm{~Hz}, \mathrm{H}-1\right), 5.13\left(\mathrm{~d}, 1 \mathrm{H},{ }^{3} J_{m-\mathrm{H}, o-\mathrm{H}}=6.5 \mathrm{~Hz}, m-\mathrm{H}\right.$ of $p$-cymene), $5.15\left(\mathrm{~d}, 1 \mathrm{H},{ }^{3} J_{\mathrm{H}-1, \mathrm{H}-2}=3.4 \mathrm{~Hz}, \mathrm{H}-1\right), 5.16(\mathrm{~d}$, $\left.1 \mathrm{H},{ }^{3} J_{\mathrm{H}-1, \mathrm{H}-2}=3.4 \mathrm{~Hz}, \mathrm{H}-1\right), 5.25\left(\mathrm{~d}, 1 \mathrm{H},{ }^{3} J_{o-\mathrm{H}, m-\mathrm{H}}=6.5 \mathrm{~Hz}\right.$, $o$-H of $p$-cymene), 7.32-7.40 $(3 \mathrm{H}, m-\mathrm{H}, p-\mathrm{H}), 8.03-8.11(2 \mathrm{H}$, $o$-H) ppm; ${ }^{13} \mathrm{C}\left\{{ }^{1} \mathrm{H}\right\} \mathrm{NMR}\left(125.8 \mathrm{MHz}, \mathrm{CDCl}_{3}, 25{ }^{\circ} \mathrm{C}\right) \delta$ (assignment by HSQC) $16.77\left(\mathrm{CH}_{3}\right.$ of $p$-cymene), 20.80, 21.24 $\left(\mathrm{CH}_{3}{ }^{\mathrm{iPr}}\right.$ of $p$-cymene $), 23.46\left(\mathrm{~d},{ }^{1} J_{\mathrm{C}, \mathrm{P}}=25.8 \mathrm{~Hz}, \mathrm{C}-6^{\mathrm{A}}\right), 28.57$ $\left(\mathrm{d},{ }^{1} J_{\mathrm{C}, \mathrm{P}}=26.0 \mathrm{~Hz}, \mathrm{C}-6^{\mathrm{B}}\right), 28.95(\mathrm{CH}$ of $p$-cymene), 56.36, $56.97,57.09,57.63,57.68,57.83[\times 2], 57.99,58.03,58.12$, $58.19,58.61,59.40,60.19,60.31,60.42,60.46,60.93,60.97$ $(\mathrm{OMe}), 65.82\left(\mathrm{~d},{ }^{2} J_{\mathrm{C}, \mathrm{P}}=11.1 \mathrm{~Hz}, \mathrm{C}-5^{\mathrm{B}}\right), 67.61\left(\mathrm{~d},{ }^{2} J_{\mathrm{C}, \mathrm{P}}=9.3\right.$ Hz, C-5 ${ }^{\mathrm{A}}$ ), 69.61 (C-5), 69.63 (C-6), 69.75, 69.93 (C-5), 69.99, $70.06[\times 2], 70.13(\mathrm{C}-6), 70.34,70.96(\mathrm{C}-5), 74.88\left(\mathrm{~d},{ }^{3} J_{\mathrm{C}, \mathrm{P}}=\right.$ $\left.4.4 \mathrm{~Hz}, \mathrm{C}-4^{\mathrm{A}}\right), 79.29,79.34,79.40,79.55,80.06[\times 2], 80.48$, $80.53,80.62[\times 2], 80.67,80.69,80.81,80.85,80.95,81.23$, $81.26,81.41,82.89$ (C-2, C-3, C-4), 83.45, 83.65 ( $\mathrm{C}_{\text {ortho }}$ of $p$-cymene $), 83.84\left(\mathrm{C}_{\text {meta }}\right.$ of $p$-cymene $), 84.43\left(\mathrm{C}-4^{\mathrm{B}}\right), 88.01$ ( $\mathrm{C}_{\text {meta }}$ of $p$-cymene), 95.54 (C-1), 95.62 ( $\mathrm{C}_{\text {ipso }}$ of $p$-cymene), 96.42, 97.94, 98.35, 98.76 [×2], $98.86(\mathrm{C}-1), 108.11\left(\mathrm{C}_{\text {ipso }}\right.$ of p-cymene $), 126.06,126.13\left(\mathrm{C}_{\text {meta }}\right), 128.94\left(\mathrm{C}_{\text {para }}\right), 130.68$, $130.82\left(\mathrm{C}_{\text {ortho }}\right), 134.91\left(\mathrm{~d},{ }^{1} J_{\mathrm{C}, \mathrm{P}}=38.5 \mathrm{~Hz}, \mathrm{C}_{\text {ipso }}\right.$ ) ppm; ${ }^{31} \mathrm{P}\left\{{ }^{1} \mathrm{H}\right\}$ NMR $\left(161.9 \mathrm{MHz}, \mathrm{CDCl}_{3}, 25^{\circ} \mathrm{C}\right) \delta 22.8$ (s) ppm; elemental analysis (\%) calcd for $\mathrm{C}_{77} \mathrm{H}_{125} \mathrm{Cl}_{2} \mathrm{O}_{33} \mathrm{PRu} \cdot \mathrm{CH}_{2} \mathrm{Cl}_{2}$ $(1781.75$ + 84.93): C, 50.19; H, 6.86; found: C, 50.03; H, 6.78; MS (ESI-TOF): $m / z(\%): 1803.62(100)[\mathrm{M}+\mathrm{Na}]^{+}$. 10a and 10b: A solution of HUGPHOS-2 (0.100 g, $0.07 \mathrm{mmol})$ in $\mathrm{CH}_{2} \mathrm{Cl}_{2}(5 \mathrm{~mL})$ was added dropwise to a solution of $\left[\mathrm{Rh}(\mathrm{CO})_{2} \mathrm{Cl}\right]_{2}(0.016 \mathrm{~g}, 0.04 \mathrm{mmol})$ in $\mathrm{CH}_{2} \mathrm{Cl}_{2}(5 \mathrm{~mL})$ under vigorous stirring at room temperature. The reaction mixture was stirred for $1 \mathrm{~h}$ before being evaporated to dryness in vacuo to afford quantitatively a mixture of $\mathbf{1 0 a}$ and $\mathbf{1 0 b}(\mathbf{1 0 a} / \mathbf{1 0 b}, 85: 15$, $0.114 \mathrm{~g}, 99 \%)$ as a brown solid. $R_{\mathrm{f}}\left(\mathrm{SiO}_{2}\right)=\mathrm{dec} ; \mathrm{mp}>250{ }^{\circ} \mathrm{C}$; Selected spectroscopic data: ${ }^{13} \mathrm{C}\left\{{ }^{1} \mathrm{H}\right\}$ NMR $(125.8 \mathrm{MHz}$, $\left.\mathrm{CDCl}_{3}, 25^{\circ} \mathrm{C}\right) \delta 181.12-182.82(\mathrm{~m}, \mathrm{CO}), 187.24-189.73(\mathrm{~m}$, $\mathrm{CO}) \mathrm{ppm} ;{ }^{31} \mathrm{P}\left\{{ }^{1} \mathrm{H}\right\} \mathrm{NMR}\left(161.9 \mathrm{MHz}, \mathrm{CDCl}_{3}, 25{ }^{\circ} \mathrm{C}\right) \delta 13.9$ $\left(\mathbf{1 0 b}, \mathrm{d},{ }^{1} J_{\mathrm{P}, \mathrm{Rh}}=121 \mathrm{~Hz}\right), 20.1\left(\mathbf{1 0 a}, \mathrm{d},{ }^{1} J_{\mathrm{P}, \mathrm{Rh}}=124 \mathrm{~Hz}\right) \mathrm{ppm}$; IR: 2090 (s, CO), 2005 (s, CO), 1985 (s, CO) cm $\mathrm{cm}^{-1}$; elemental analysis (\%) calcd for $\mathrm{C}_{69} \mathrm{H}_{111} \mathrm{ClO}_{35} \mathrm{PRh} \cdot 3 \mathrm{CH}_{2} \mathrm{Cl}_{2}(1669.93+$ 254.80): C 44.99, H 6.31 found: C 45.01, H 6.99; MS (ESI-TOF): $m / z(\%): 1605.58(100)[\mathrm{M}-\mathrm{CO}-\mathrm{Cl}]^{+}, 1663.54$ (20) $[M-\mathrm{CO}+\mathrm{Na}]^{+}$; MS (ESI-TOF): $m / z(\%): 1675.55(100)$ $[\mathrm{M}-\mathrm{CO}+\mathrm{Cl}]^{-}$; MS (MALDI-TOF): $m / z(\%): 1605.58$ (100) $[\mathrm{M}-\mathrm{CO}-\mathrm{Cl}]^{+}, 1719.69(5)[\mathrm{M}+\mathrm{CO}+\mathrm{Na}]^{+}$.

11: A solution of $\left[\mathrm{Rh}(\mathrm{CO})_{2} \mathrm{Cl}\right]_{2}(0.080 \mathrm{~g}, 0.20 \mathrm{mmol})$ in $\mathrm{CH}_{2} \mathrm{Cl}_{2}(7 \mathrm{~mL})$ was added dropwise to a solution of HUGPHOS-2 $(0.100 \mathrm{~g}, 0.07 \mathrm{mmol})$ in $\mathrm{CH}_{2} \mathrm{Cl}_{2}(5 \mathrm{~mL})$ under vigorous stirring at room temperature. After $1 \mathrm{~h}$, the volume of the reaction mixture was reduced to $5 \mathrm{~mL}$ and pentane $(40 \mathrm{~mL})$ was added in order to precipitate unreacted $\left[\mathrm{Rh}(\mathrm{CO})_{2} \mathrm{Cl}\right]_{2}$, which was removed by filtration on a pad of Celite. The resulting solution was evaporated to dryness in vacuo to afford quantitatively 11 as a brown powder $(0.103 \mathrm{~g}, 83 \%)$. mp dec $>250{ }^{\circ} \mathrm{C}$; ${ }^{1} \mathrm{H}$ NMR $\left(500.1 \mathrm{MHz}, \mathrm{CDCl}_{3}, 25{ }^{\circ} \mathrm{C}\right) \delta$ (assignment by combined COSY and HSQC $)=1.91\left(\mathrm{q}, 1 \mathrm{H},{ }^{2} J_{\mathrm{H}-6 \mathrm{a}, \mathrm{H}-6 \mathrm{~b}}=\right.$ $\left.{ }^{2} J_{\mathrm{H}-6 \mathrm{a}, \mathrm{P}}={ }^{3} J_{\mathrm{H}-6 \mathrm{a}, \mathrm{H}-5}=15.4 \mathrm{~Hz}, \mathrm{H}-6 \mathrm{a}^{\mathrm{B}}\right), 2.17\left(\mathrm{t}, 1 \mathrm{H},{ }^{2} J_{\mathrm{H}-6 \mathrm{a}, \mathrm{H}-6 \mathrm{~b}}\right.$ $\left.={ }^{2} J_{\mathrm{H}-6 \mathrm{a}, \mathrm{P}}=14.2 \mathrm{~Hz}, \mathrm{H}-6 \mathrm{a}^{\mathrm{A}}\right), 3.02\left(\mathrm{~m}, 1 \mathrm{H}, \mathrm{H}-6 \mathrm{~b}^{\mathrm{B}}\right), 3.20(\mathrm{~s}, 3 \mathrm{H}$, $\mathrm{OMe}), 3.30$ (s, $3 \mathrm{H}, \mathrm{OMe}), 3.32$ (s, $3 \mathrm{H}, \mathrm{OMe}), 3.36(\mathrm{~s}, 3 \mathrm{H}$, $\mathrm{OMe}), 3.45$ (s, 6H, OMe), 3.46 (s, 3H, OMe), 3.48 (s, 3H, $\mathrm{OMe}), 3.50$ (s, 6H, OMe), 3.52 (s, 3H, OMe), 3.53 (s, 3H, $\mathrm{OMe}), 3.59$ (s, 6H, OMe), 3.62 (s, 3H, OMe), 3.64 (s, 3H, $\mathrm{OMe}), 3.65$ (s, 3H, OMe), 3.68 (s, 3H, OMe), 3.76 (s, 3H, OMe), 3.13-3.79 (26H, H-2, H-3, H-4, H-6), 3.80-3.92 (4H, H-6), 3.93-4.01 (4H, H-5, H-6), 4.07-4.13 (3H, H-5, H-6), 4.36 $\left(\mathrm{dt}, 1 \mathrm{H},{ }^{3} J_{\mathrm{H}-5, \mathrm{H}-4}={ }^{3} J_{\mathrm{H}-5, \mathrm{H}-6 \mathrm{~b}}=10.5 \mathrm{~Hz},{ }^{3} J_{\mathrm{H}-5, \mathrm{H}-6 \mathrm{a}}=15.4 \mathrm{~Hz}\right.$, $\left.\mathrm{H}-5^{\mathrm{B}}\right), 4.95\left(\mathrm{~d}, 1 \mathrm{H},{ }^{3} J_{\mathrm{H}-1, \mathrm{H}-2}=3.7 \mathrm{~Hz}, \mathrm{H}-1\right), 5.00(\mathrm{~d}, 1 \mathrm{H}$, $\left.{ }^{3} J_{\mathrm{H}-1, \mathrm{H}-2}=4.6 \mathrm{~Hz}, \mathrm{H}-1\right), 5.03\left(\mathrm{~d}, 1 \mathrm{H},{ }^{3} J_{\mathrm{H}-1, \mathrm{H}-2}=3.7 \mathrm{~Hz}, \mathrm{H}-1\right)$, 5.08-5.11 (3H, H-1), $5.20\left(\mathrm{~d}, 1 \mathrm{H},{ }^{3} J_{\mathrm{H}-1, \mathrm{H}-2}=3.7 \mathrm{~Hz}, \mathrm{H}-1\right)$, 5.35-5.45 (m, $\left.1 \mathrm{H}, \mathrm{H}-5^{\mathrm{A}}\right), 7.42-7.46(3 \mathrm{H}, m-\mathrm{H}, p-\mathrm{H}), 7.82-7.87$ $(2 \mathrm{H}, o-\mathrm{H}) \mathrm{ppm} ;{ }^{13} \mathrm{C}\left\{{ }^{1} \mathrm{H}\right\} \mathrm{NMR}\left(125.8 \mathrm{MHz}, \mathrm{CDCl}_{3}, 25^{\circ} \mathrm{C}\right) \delta$ (assignment by HSQC) $=32.32\left(\mathrm{~d},{ }^{1} J_{\mathrm{C}, \mathrm{P}}=29.3 \mathrm{~Hz}, \mathrm{C}-6^{\mathrm{A}}\right)$, $35.77\left(\mathrm{~d},{ }^{1} J_{\mathrm{C}, \mathrm{P}}=29.3 \mathrm{~Hz}, \mathrm{C}-6^{\mathrm{B}}\right), 56.74,57.18,57.26,57.63$ $[\times 2], 57.78,57.91,57.96,57.99,58.06,58.08,58.29,60.13$, $60.31,60.54[\times 2], 60.56,60.70,60.83(\mathrm{OMe}), 63.30\left(\mathrm{C}-5^{\mathrm{A}}\right)$, 69.43, 69.50, 69.68, 69.90, $69.94(\mathrm{C}-5), 70.01,70.24,70.44$, $70.60,70.76(\mathrm{C}-6), 71.31\left(\mathrm{~d},{ }^{2} J_{\mathrm{C}, \mathrm{P}}=15.9 \mathrm{~Hz}, \mathrm{C}-5^{\mathrm{B}}\right), 78.57$, 
$79.04,79.79[\times 2], 80.17,80.23[\times 2], 80.47,80.51,80.57,80.90$, $81.05,81.12,81.32,81.40,81.68,81.76,82.14,83.09$ (C-2, $\mathrm{C}-3, \mathrm{C}-4), 84.17\left(\mathrm{~d},{ }^{3} J_{\mathrm{C}, \mathrm{P}}=10.7 \mathrm{~Hz}, \mathrm{C}-4^{\mathrm{B}}\right), 88.02\left(\mathrm{~d},{ }^{3} J_{\mathrm{C}, \mathrm{P}}=\right.$ $\left.4.6 \mathrm{~Hz}, \mathrm{C}-4^{\mathrm{A}}\right), 96.39,97.66,97.70,98.52,98.66,99.37,99.79$ $(\mathrm{C}-1), 127.62,127.70\left(\mathrm{C}_{\text {meta }}\right), 130.08\left(\mathrm{C}_{\text {para }}\right), 130.56,130.64$ $\left(\mathrm{C}_{\text {ortho }}\right), 135.13\left(\mathrm{~d},{ }^{1} J_{\mathrm{C}, \mathrm{P}}=57.5 \mathrm{~Hz}, \mathrm{C}_{\text {ipso }}\right), 176.16[\times 2](\mathrm{d}$, $\left.{ }^{1} J_{\mathrm{C}, \mathrm{Rh}}=77.2 \mathrm{~Hz}, \mathrm{CO}\right), 177.63\left(\mathrm{dd},{ }^{1} J_{\mathrm{C}, \mathrm{Rh}}=71.9 \mathrm{~Hz},{ }^{2} J_{\mathrm{C}, \mathrm{P}}=\right.$ $22.8 \mathrm{~Hz}, \mathrm{CO}) \mathrm{ppm} ;{ }^{31} \mathrm{P}\left\{{ }^{1} \mathrm{H}\right\} \mathrm{NMR}\left(161.9 \mathrm{MHz}, \mathrm{CDCl}_{3}, 25^{\circ} \mathrm{C}\right)$ $\delta 40.5\left(\mathrm{~d},{ }^{1} J_{\mathrm{P}, \mathrm{Rh}}=172 \mathrm{~Hz}\right) \mathrm{ppm}$; IR: 2086 (vs, CO), 2026 (vs, $\mathrm{CO}), 2004(\mathrm{~s}, \mathrm{CO}) \mathrm{cm}^{-1}$; We do not provide microanalytical data for this compound because of strong hydration; MS (ESI-TOF): $m / z$ (\%): 1799.44 (70) $[\mathrm{M}-\mathrm{Cl}]^{+}, 1857.40(100)$ $[\mathrm{M}+\mathrm{Na}]^{+}$.

General procedure for palladium-catalysed Heck crosscoupling reactions: In an oven-dried Schlenk tube, a solution of $\left[\mathrm{Pd}(\mathrm{OAc})_{2}\right]$ in DMF, a solution of HUGPHOS-1/2 or WIDEPHOS ligands in DMF, aryl bromide (1 equiv), styrene (2 equiv), $\mathrm{Cs}_{2} \mathrm{CO}_{3}$ (2 equiv), decane (internal reference) and additional DMF were introduced under an inert atmosphere. The reaction mixture was heated for $1 \mathrm{~h}$. After cooling to room temperature, a small amount $(0.5 \mathrm{~mL})$ of the resulting solution was passed through a Millipore filter and analyzed by GC. Each experiment was repeated twice and the conversion values given in Table 3 and Table 4 correspond to the mean value from two catalytic tests.

\section{Supporting Information}

\section{Supporting Information File 1}

Copies of NMR spectra for compounds $2,3,6,7,8,10 a$ and $\mathbf{1 0 b}$ and $\mathbf{1 1 .}$

[http://www.beilstein-journals.org/bjoc/content/ supplementary/1860-5397-10-249-S1.pdf]

\section{Acknowledgements}

This research was supported by the Région Alsace and the Centre International pour la Recherche aux Frontières de la Chimie (CIRFC).

\section{References}

1. Littke, A. F.; Fu, G. C. J. Org. Chem. 1999, 64, 10-11. doi:10.1021/j09820059

2. Stambuli, J. P.; Stauffer, S. R.; Shaughnessy, K. H.; Hartwig, J. F. J. Am. Chem. Soc. 2001, 123, 2677-2678. doi:10.1021/ja0058435

3. Littke, A. F.; Fu, G. C. J. Am. Chem. Soc. 2001, 123, 6989-7000. doi:10.1021/ja010988c

4. Wolfe, J. P.; Singer, R. A.; Yang, B. H.; Buchwald, S. L. J. Am. Chem. Soc. 1999, 121, 9550-9561. doi:10.1021/ja992130h

5. Kataoka, N.; Shelby, Q.; Stambuli, J. P.; Hartwig, J. F. J. Org. Chem. 2002, 67, 5553-5566. doi:10.1021/j0025732j
6. Walker, S. D.; Barder, T. E.; Martinelli, J. R.; Buchwald, S. L. Angew. Chem., Int. Ed. 2004, 43, 1871-1876. doi:10.1002/anie.200353615

7. Ohzu, Y.; Goto, K.; Kawashima, T. Angew. Chem., Int. Ed. 2003, 42, 5714-5717. doi:10.1002/anie.200352616

8. Iwasawa, T.; Komano, T.; Tajima, A.; Tokunaga, M.; Obora, Y.; Fujihara, T.; Tsuji, Y. Organometallics 2006, 25, 4665-4669. doi:10.1021/om060615q

9. Ohta, H.; Tokunaga, M.; Obora, Y.; Iwai, T.; Iwasawa, T.; Fujihara, T.; Tsuji, Y. Org. Lett. 2007, 9, 89-92. doi:10.1021/ol0626138

10. Dodds, D. L.; Boele, M. D. K.; van Strijdonck, G. P. F.; de Vries, J. G.; van Leeuwen, P. W. N. M.; Kamer, P. C. J. Eur. J. Inorg. Chem. 2012, 1660-1671. doi:10.1002/Ejic.201101271

11. Fujihara, T.; Yoshida, S.; Ohta, H.; Tsuji, Y. Angew. Chem., Int. Ed. 2008, 47, 8310-8314. doi:10.1002/anie.200802683

12. Snelders, D. J. M.; van Koten, G.; Klein Gebbink, R. J. M. J. Am. Chem. Soc. 2009, 131, 11407-11416. doi:10.1021/ja904042h

13. Kwong, F. Y.; Chan, A. S. C. Synlett 2008, 1440-1448. doi:10.1055/s-2008-1078425

14. Surry, D. S.; Buchwald, S. L. Angew. Chem., Int. Ed. 2008, 47, 6338-6361. doi:10.1002/anie.200800497

15. Monnereau, L.; Sémeril, D.; Matt, D.; Toupet, L. Chem. - Eur. J. 2010, 16, 9237-9247. doi:10.1002/Chem.200903390

16. Pruett, R. L.; Smith, J. A. J. Org. Chem. 1969, 34, 327-330. doi:10.1021/jo01254a015

17. Dabbawala, A. A.; Bajaj, H. C.; Jasra, R. V. J. Mol. Catal. A 2009, 302, 97-106. doi:10.1016/j.molcata.2008.12.002

18. Dabbawala, A. A.; Jasra, R. V.; Bajaj, H. C. Catal. Commun. 2010, 11, 616-619. doi:10.1016/j.catcom.2010.01.007

19. Kubis, C.; Ludwig, R.; Sawall, M.; Neymeyr, K.; Börner, A.; Wiese, K.-D.; Hess, D.; Franke, R.; Selent, D. ChemCatChem 2010, 2 , 287-295. doi:10.1002/cctc.200900292

20. Kubis, C.; Selent, D.; Sawall, M.; Ludwig, R.; Neymeyr, K.; Baumann, W.; Franke, R.; Börner, A. Chem. - Eur. J. 2012, 18, 8780-8794. doi:10.1002/chem.201200603

21. Tricas, H.; Diebolt, O.; van Leeuwen, P. W. N. M. J. Catal. 2013, 298, 198-205. doi:10.1016/j.jcat.2012.11.031

22. van Leeuwen, P. W. N. M.; Claver, C. Rhodium Catalyzed Hydroformylation; Kluwer Academic Publishers: Dordrecht, 2002.

23. Selent, D.; Wiese, K.-D.; Röttger, D.; Börner, A. Angew. Chem., Int. Ed 2000, 39, 1639-1641. doi:10.1002/(Sici)1521-3773(20000502)39:9<1639::Aid-Anie1639>3.0. Co;2-C

24. Breit, B.; Winde, R.; Mackewitz, T.; Paciello, R.; Harms, K. Chem. - Eur. J. 2001, 7, 3106-3121. doi:10.1002/1521-3765(20010716)7:14<3106::Aid-Chem3106>3.0.Co; 2-Y

25. Baber, R. A.; Clarke, M. L.; Heslop, K. M.; Marr, A. C.; Orpen, A. G.; Pringle, P. G.; Ward, A.; Zambrano-Williams, D. E. Dalton Trans. 2005, 1079-1085. doi:10.1039/b418259f

26. Clarke, M. L. Curr. Org. Chem. 2005, 9, 701-718. doi:10.2174/1385272053764980

27. Rafter, E.; Gilheany, D. G.; Reek, J. N. H.; van Leeuwen, P. W. N. M. ChemCatChem 2010, 2, 387-391. doi:10.1002/cctc.200900313

28. Dabbawala, A. A.; Jasra, R. V.; Bajaj, H. C. Catal. Commun. 2011, 12, 403-407. doi:10.1016/j.catcom.2010.10.026

29. Dabbawala, A. A.; Bajaj, H. C.; Rao, G. V. S.; Abdi, S. H. R. Appl. Catal., A: Gen. 2012, 419-420, 185-193. doi:10.1016/j.apcata.2012.01.027 
30. Bellini, R.; Reek, J. N. Chem. - Eur. J. 2012, 18, 7091-7099. doi:10.1002/chem.201200225

31. Bellini, R.; Chikkali, S. H.; Berthon-Gelloz, G.; Reek, J. N. H. Angew. Chem., Int. Ed. 2011, 50, 7342-7345. doi:10.1002/Anie.201101653

32. Bocokić, V.; Kalkan, A.; Lutz, M.; Spek, A. L.; Gryko, D. T.; Reek, J. N. H. Nat. Commun. 2013, 4, No. 2670. doi:10.1038/Ncomms3670

33. Agbossou, F.; Carpentier, J.-F.; Mortreux, A. Chem. Rev. 1995, 95, 2485-2506. doi:10.1021/Cr00039a008

34. Claver, C.; Diéguez, M.; Pàmies, O.; Castillón, S. Top. Organomet. Chem. 2006, 18, 35-64. doi:10.1007/3418_016

35. Klosin, J.; Landis, C. R. Acc. Chem. Res. 2007, 40, 1251-1259. doi:10.1021/Ar7001039

36. Gual, A.; Godard, C.; Castillón, S.; Claver, C. Tetrahedron: Asymmetry 2010, 21, 1135-1146. doi:10.1016/j.tetasy.2010.05.037

37. Franke, R.; Selent, D.; Börner, A. Chem. Rev. 2012, 112, 5675-5732. doi:10.1021/cr3001803

38. Engeldinger, E.; Poorters, L.; Armspach, D.; Matt, D.; Toupet, L. Chem. Commun. 2004, 634-635. doi:10.1039/B315802K

39. Gramage-Doria, R.; Rodriguez-Lucena, D.; Armspach, D.; Egloff, C.; Jouffroy, M.; Matt, D.; Toupet, L. Chem. - Eur. J. 2011, 17, 3911-3921. doi:10.1002/chem.201002541

40. Machut-Binkowski, C.; Legrand, F.-X.; Azaroual, N.; Tilloy, S.; Monflier, E. Chem. - Eur. J. 2010, 16, 10195-10201. doi:10.1002/Chem.201000379

41. Legrand, F.-X.; Six, N.; Slomianny, C.; Bricout, H.; Tilloy, S.; Monflier, E. Adv. Synth. Catal. 2011, 353, 1325-1334. doi:10.1002/Adsc.201000917

42. Tran, D. N.; Legrand, F.-X.; Menuel, S.; Bricout, H.; Tilloy, S.; Monflier, E. Chem. Commun. 2012, 48, 753-755. doi:10.1039/C1cc16326d

43. Takashima, Y.; Uramatsu, K.; Jomori, D.; Harima, A.; Otsubo, M.; Yamaguchi, H.; Harada, A. ACS Macro Lett. 2013, 2, 384-387. doi:10.1021/Mz4001942

44. Jouffroy, M.; Gramage-Doria, R.; Armspach, D.; Sémeril, D.; Oberhauser, W.; Matt, D.; Toupet, L. Angew. Chem., Int. Ed. 2014, 53, 3937-3940. doi:10.1002/anie.201311291

45. Gramage-Doria, R. Large Cavity Cyclodextrin-Based Macrocyclic Ligands: Synthesis, Coordination and Catalytic Properties. Ph.D. Thesis, Université de Strasbourg, Strasbourg, 2012.

46. Engeldinger, E.; Armspach, D.; Matt, D.; Jones, P. G.; Welter, R. Angew. Chem., Int. Ed. 2002, 41, 2593-2596. doi:10.1002/1521-3773(20020715)41:14<2593::Aid-Anie2593>3.0.Co; 2-M

47. Gramage-Doria, R.; Armspach, D.; Matt, D. Coord. Chem. Rev. 2013, 257, 776-816. doi:10.1016/J.Ccr.2012.10.006

48. Kaufmann, W.; Venanzi, L. M.; Albinati, A. Inorg. Chem. 1988, 27 , 1178-1187. doi:10.1021/lc00280a018

49. Espinet, P.; Martínez-Ilarduya, J. M.; Pérez-Briso, C.; Casado, A. L.; Alonso, M. A. J. Organomet. Chem. 1998, 551, 9-20. doi:10.1016/S0022-328X(97)00424-5

50. Bartolomé, C.; Espinet, P.; Vicente, L.; Villafañe, F.; Charmant, J. P. H.; Orpen, A. G. Organometallics 2002, 21, 3536-3543. doi:10.1021/om020198r

51. Vicente, J.; Arcas, A. Coord. Chem. Rev. 2005, 249, 1135-1154. doi:10.1016/j.ccr.2004.11.005

52. Gramage-Doria, R.; Armspach, D.; Matt, D.; Toupet, L. Angew. Chem., Int. Ed. 2011, 50, 1554-1559. doi:10.1002/anie.201005169
53. Engeldinger, E.; Armspach, D.; Matt, D.; Jones, P. G. Chem. - Eur. J. 2003, 9, 3091-3105. doi:10.1002/chem.200304806

54. Li Wu, M.; Desmond, M. J.; Drago, R. S. Inorg. Chem. 1979, 18, 679-686. doi:10.1021/ic50193a030

55. Uguagliati, P.; Deganello, G.; Busetto, L.; Belluco, U. Inorg. Chem. 1969, 8, 1625-1630. doi:10.1021/ic50078a011

56. Deganello, G.; Uguagliati, P.; Crociani, B.; Belluco, U. J. Chem. Soc. A 1969, 2726-2729. doi:10.1039/J19690002726

57. Wood, C. D.; Garrou, P. E. Organometallics 1984, 3, 170-174. doi:10.1021/Om00079a030

58. Leigh, J. S.; Whitmire, K. H. Acta Crystallogr., Sect. C 1989, 45, 210-212. doi:10.1107/S0108270188010960

59. Bartik, T.; Krümmung, T.; Happ, B.; Sieker, A.; Markó, L.; Boese, R.; Ugo, R.; Zucchi, C.; Pályi, G. Catal. Lett. 1993, 19, 383-389. doi:10.1007/Bf00767082

60. Miessler, G. L.; Tarr, D. A. Inorganic Chemistry; Pearson Prentice Hall: Upper Saddle River, NJ, 2011; pp 534-538.

61. Adint, T. T.; Wong, G. W.; Landis, C. R. J. Org. Chem. 2013, 78, 4231-4238. doi:10.1021/jo400525w

62. Nelsen, E. R.; Landis, C. R. J. Am. Chem. Soc. 2013, 135, 9636-9639. doi:10.1021/Ja404799m

63. Noonan, G. M.; Cobley, C. J.; Mahoney, T.; Clarke, M. L. Chem. Commun. 2014, 50, 1475-1477. doi:10.1039/C3cc48823c

64. Ziegler, C. B., Jr.; Heck, R. F. J. Org. Chem. 1978, 43, 2941-2946. doi:10.1021/Jo00409a001

65. Heck, R. F.; Nolley, J. P. J. Org. Chem. 1972, 37, 2320-2322. doi:10.1021/jo00979a024

66. Gillie, A.; Stille, J. K. J. Am. Chem. Soc. 1980, 102, 4933-4941. doi:10.1021/Ja00535a018

67. Sliger, M. D.; Broker, G. A.; Griffin, S. T.; Rogers, R. D.; Shaughnessy, K. H. J. Organomet. Chem. 2005, 690, 1478-1486. doi:10.1016/J.Jorganchem.2004.12.022

68. Gramage-Doria, R.; Armspach, D.; Matt, D.; Toupet, L. Chem. - Eur. J. 2012, 18, 10813-10816. doi:10.1002/Chem.201201403

69. Sémeril, D.; Lejeune, M.; Jeunesse, C.; Matt, D. J. Mol. Catal. A 2005, 239, 257-262. doi:10.1016/j.molcata.2005.06.024

70. El Moll, H.; Sémeril, D.; Matt, D.; Youinou, M.-T.; Toupet, L. Org. Biomol. Chem. 2009, 7, 495-501. doi:10.1039/B813373E

71. Shaughnessy, K. H.; Kim, P.; Hartwig, J. F. J. Am. Chem. Soc. 1999, 121, 2123-2132. doi:10.1021/ja983419m

72. Kanagaraj, K.; Pitchumani, K. Chem. - Eur. J. 2013, 19, 14425-14431. doi:10.1002/Chem.201301863

73. Ben-David, Y.; Portnoy, M.; Gozin, M.; Milstein, D. Organometallics 1992, 11, 1995-1996. doi:10.1021/om00042a008

74. Crisp, G. T. Chem. Soc. Rev. 1998, 27, 427-436. doi:10.1039/A827427Z

75. Beletskaya, I. P.; Cheprakov, A. V. Chem. Rev. 2000, 100, 3009-3066. doi:10.1021/Cr9903048

76. Whitcombe, N. J.; Hii, K. K.; Gibson, S. E. Tetrahedron 2001, 57, 7449-7476. doi:10.1016/S0040-4020(01)00665-2

77. Surawatanawong, P.; Fan, Y.; Hall, M. B. J. Organomet. Chem. 2008, 693, 1552-1563. doi:10.1016/j.jorganchem.2008.01.034

78. Amatore, C.; Jutand, A. Acc. Chem. Res. 2000, 33, 314-321. doi:10.1021/ar980063a

79. Knowles, J. P.; Whiting, A. Org. Biomol. Chem. 2007, 5, 31-44. doi:10.1039/B611547k

80. Jutand, A. Mechanisms of the Mizoroki-Heck Reaction; John Wiley \& Sons, Ltd.: Chichester, United Kingdom, 2009. 
81. Sumimoto, M.; Kuroda, T.; Yokogawa, D.; Yamamoto, H.; Hori, K. J. Organomet. Chem. 2012, 710, 26-35.

doi:10.1016/J.Jorganchem.2012.03.008

82. van Strijdonck, G. P. F.; Boele, M. D. K.; Kamer, P. C. J.;

de Vries, J. G.; van Leeuwen, P. W. N. M. Eur. J. Inorg. Chem. 1999, 1073-1076.

doi:10.1002/(SICI)1099-0682(199907)1999:7<1073::AID-EJIC1073>3. $0 . \mathrm{CO} ; 2-\mathrm{T}$

83. Engeldinger, E.; Armspach, D.; Matt, D. Angew. Chem., Int. Ed. 2001, 40, 2526-2529.

doi:10.1002/1521-3773(20010702)40:13<2526::AID-ANIE2526>3.0.CO ;2-T

84. Wong, Y. T.; Yang, C.; Ying, K.-C.; Jia, G. Organometallics 2002, 21, 1782-1787. doi:10.1021/Om010995+

85. Schlatter, A.; Kundu, M. K.; Woggon, W.-D. Angew. Chem., Int. Ed. 2004, 43, 6731-6734. doi:10.1002/anie.200460102

86. Liu, K.; Häussinger, D.; Woggon, W.-D. Synlett 2007, 2298-2300. doi:10.1055/s-2007-985569

87. Schlatter, A.; Woggon, W.-D. Adv. Synth. Catal. 2008, 350, 995-1000. doi:10.1002/adsc.200700558

88. Guitet, M.; Zhang, P.; Marcelo, F.; Tugny, C.; Jiménez-Barbero, J.; Buriez, O.; Amatore, C.; Mouriès-Mansuy, V.; Goddard, J.-P.; Fensterbank, L.; Zhang, Y.; Roland, S.; Ménand, M.; Sollogoub, M. Angew. Chem., Int. Ed. 2013, 52, 7213-7218. doi:10.1002/anie.201301225

89. Hartley, F. R. The Chemistry of Platinum and Palladium; Wiley: New York, 1973.

\section{License and Terms}

This is an Open Access article under the terms of the Creative Commons Attribution License (http://creativecommons.org/licenses/by/2.0), which permits unrestricted use, distribution, and reproduction in any medium, provided the original work is properly cited.

The license is subject to the Beilstein Journal of Organic Chemistry terms and conditions:

(http://www.beilstein-journals.org/bjoc)

The definitive version of this article is the electronic one which can be found at: $\underline{\text { doi: } 10.3762 / \text { bjoc. } 10.249}$ 